\title{
Circumpolar measurements of speciated mercury, ozone and carbon monoxide in the boundary layer of the Arctic Ocean
}

\author{
J. Sommar ${ }^{1}$, M. E. Andersson ${ }^{2}$, and H.-W. Jacobi ${ }^{3,4}$ \\ ${ }^{1}$ State key Laboratory of Environmental Geochemistry, Institute of Geochemistry, Chinese Academy of Sciences, \\ Guiyang 550002, China \\ ${ }^{2}$ Department of Chemistry, Göteborg University, 41296 Göteborg, Sweden \\ ${ }^{3}$ CNRS/Université Joseph Fourier - Grenoble 1, Laboratoire de Glaciologie et Géophysique de l'Environnement, 54 Rue \\ Molière, 38400 St Martin d'Hères, France \\ ${ }^{4}$ Alfred Wegener Institute for Polar and Marine Research, Am Handelshafen 12, 27570 Bremerhaven, Germany
}

Received: 19 August 2009 - Published in Atmos. Chem. Phys. Discuss.: 5 October 2009

Revised: 10 May 2010 - Accepted: 10 May 2010 - Published: 1 June 2010

\begin{abstract}
Using the Swedish icebreaker Oden as a platform, continuous measurements of airborne mercury (gaseous elemental mercury $\left(\mathrm{Hg}^{0}\right)$, divalent gaseous mercury species $\mathrm{Hg}^{\mathrm{II}} \mathrm{X}_{2}$ (g) (acronym RGM) and mercury attached to particles $(\mathrm{PHg})$ ) and some long-lived trace gases (carbon monoxide $\mathrm{CO}$ and ozone $\mathrm{O}_{3}$ ) were performed over the North Atlantic and the Arctic Ocean. The measurements were performed for nearly three months (July-September 2005) during the Beringia 2005 expedition (from Göteborg, Sweden via the proper Northwest Passage to the Beringia region Alaska Chukchi Penninsula - Wrangel Island and in-turn via a northpolar transect to Longyearbyen, Spitsbergen). The Beringia 2005 expedition was the first time that these species have been measured during summer over the Arctic Ocean going from $60^{\circ}$ to $90^{\circ} \mathrm{N}$.

During the North Atlantic transect, concentration levels of $\mathrm{Hg}^{0}, \mathrm{CO}$ and $\mathrm{O}_{3}$ were measured comparable to typical levels for the ambient mid-hemispheric average. However, a rapid increase of $\mathrm{Hg}^{0}$ in air and surface water was observed when entering the ice-covered waters of the Canadian Arctic archipelago. Large parts of the measured waters were supersaturated with respect to $\mathrm{Hg}^{0}$, reflecting a strong disequilibrium. Heading through the sea ice of the Arctic Ocean, a fraction of the strong $\mathrm{Hg}^{0}$ pulse in the water was transferred with some time-delay into the air samples collected $\sim 20 \mathrm{~m}$ above sea level. Several episodes of elevated
\end{abstract}

$\mathrm{Hg}^{0}$ in air were encountered along the sea ice route with higher mean concentration $\left(1.81 \pm 0.43 \mathrm{ng} \mathrm{m}^{-3}\right)$ compared to the marine boundary layer over ice-free Arctic oceanic waters $\left(1.55 \pm 0.21 \mathrm{ng} \mathrm{m}^{-3}\right)$. In addition, the bulk of the variance in the temporal series of $\mathrm{Hg}^{0}$ concentrations was observed during July. The Oden $\mathrm{Hg}^{0}$ observations compare in this aspect very favourably with those at the coastal station Alert. Atmospheric boundary layer $\mathrm{O}_{3}$ mixing ratios decreased when initially sailing northward. In the Arctic, an $\mathrm{O}_{3}$ minimum around 15-20 ppbV was observed during summer (July-August). Alongside the polar transect during the beginning of autumn, a steady trend of increasing $\mathrm{O}_{3}$ mixing ratios was measured returning to initial levels of the expedition $(>30 \mathrm{ppbV})$. Ambient CO was fairly stable $(84 \pm 12 \mathrm{ppbV})$ during the expedition. However, from the Beaufort Sea and moving onwards steadily increasing $\mathrm{CO}$ mixing ratios were observed $\left(0.3 \mathrm{ppbV} \mathrm{day}^{-1}\right)$. On a comparison with coeval archived $\mathrm{CO}$ and $\mathrm{O}_{3}$ data from the Arctic coastal strip monitoring sites Barrow and Alert, the observations from Oden indicate these species to be homogeneously distributed over the Arctic Ocean. Neither correlated low ozone and $\mathrm{Hg}^{0}$ events nor elevated concentrations of RGM and $\mathrm{PHg}$ were at any extent sampled, suggesting that atmospheric mercury deposition to the Arctic basin is low during the Polar summer and autumn. 


\section{Introduction}

The average residence time of gaseous elemental mercury $\left(\mathrm{Hg}^{0}\right)$ and carbon monoxide $(\mathrm{CO})$ in the lower troposphere is sufficient to make its distribution homogeneous over each hemisphere. While the seasonal cycle of $\mathrm{CO}$ exhibits a summertime minimum largely due to chemical oxidation initiated by the hydroxyl radical OH (e.g. Holloway et al., 2000), the seasonality of $\mathrm{Hg}^{0}$ is less obvious taking into consideration worldwide long-term observations (Kim et al., 2005). However, several background stations in the mid-latitudes north of $45^{\circ} \mathrm{N}$ (Kellerhals et al., 2003; Kim et al., 2005) report a wintertime $\mathrm{Hg}^{0}$ maximum. This has been attributed to seasonal trends in anthropogenic emissions and/or meteorological conditions, atmospheric oxidation processes, the height of the atmospheric mixing layer (Kock et al., 2005) and the terrestrial carbon pool (Obrist, 2007). Unlike $\mathrm{Hg}^{0}$ and $\mathrm{CO}$, the mixing ratio of ozone $\left(\mathrm{O}_{3}\right)$ in the lower troposphere reaches a maximum during summer. The Arctic atmospheric boundary layer $\mathrm{Hg}^{0}$ and $\mathrm{O}_{3}$ cycles derived from background observation sites in the European and American high Arctic (Schroeder et al., 1998; Berg et al., 2003; Helmig et al., 2007), however, exhibit large seasonal discrepancies from that of the mid-latitudes.

It is very likely that high level of neurotoxic mercury in the Arctic ecosystems is partially linked to rapid, near-complete depletion of $\mathrm{Hg}^{0}$ (MDEs) in the atmospheric boundary layer occurring episodically during the polar spring (Steffen et al., 2008). Upon reaction with reactive bromine species such as bromine atoms (Donohoue et al., 2006) hundred(s) of tons of oxidised mercury $\left(\mathrm{Hg}^{\mathrm{II}}\right)$ are produced and perennially deposited into the Arctic environment (Ariya et al., 2004; Banic et al., 2003; Dastoor et al., 2008; Skov et al., 2004). The relative magnitude of this sink is profound, resembling almost half of the annual atmospheric input within a few weeks (Outridge et al., 2008). To a yet not well quantified, but significant degree, a back-reduction of $\mathrm{Hg}^{\mathrm{II}}$ to $\mathrm{Hg}^{0}$ occurs resulting in a re-cycling of volatile mercury to the atmosphere (Schroeder et al., 2003). However, it cannot compensate for the total deposition, and a net assimilation into the food chain occurs. The Hg levels in the traditional food of indigenous people living in the Arctic pose a threat for human pre- and neonatal neurological development (Steffen et al., 2008). Arctic marine mammals such as beluga whales frequently contain total $\mathrm{Hg}$ levels well above Canadian Federal Consumption Guidelines (Lockhart et al., 2005). Again, the fate of surplus mercury deposited to the Arctic basin during polar spring is largely unknown with reference to transport and transformation. This issue has recently been discussed in modelling papers by Hedgecock et al. (2008) and Outridge et al. (2008) in favour of less net accumulation in the abiotic reservoirs. The Beringia 2005 expedition, taking place a few months after the period of elevated deposition of $\mathrm{Hg}$ to the Arctic Ocean, offered a unique opportunity to sample vast exposed, yet unexplored areas.
During the polar spring MDEs, $\mathrm{Hg}^{0}$ is generally strongly correlated with $\mathrm{O}_{3}$ (e.g. Ebinghaus et al., 2002; Eneroth et al., 2007). The loss of tropospheric $\mathrm{O}_{3}$ and most probably $\mathrm{Hg}^{0}$ in the Arctic is initiated by catalytic heterogeneous reactions involving reactive bromine gases that originate from refined sea salt reservoirs linked to sea ice (e.g. frost flowers (Kaleschke et al., 2004; Jacobi et al., 2006) or snow on sea ice (Simpson et al., 2005)) and is activated by gas-phase photochemistry: Young ice regions with open leads tend to promote the growth of salinity-enhanced ice crystals with large effective surface areas. Hönninger (2002), Brooks et al. (2006) and Sommar et al. (2007) reported ground-based measurement of elevated $\mathrm{BrO}$ concentration in concert with air masses depleted of $\mathrm{Hg}^{0}$ and $\mathrm{O}_{3}$. Unlike $\mathrm{Hg}^{0}$ and $\mathrm{O}_{3}$, $\mathrm{CO}$ is less susceptible to bromine radical initiated degradation and hence essentially remaining chemical inert during polar spring (Sumner et al., 2002). The spatial extent of MDEs may be approximated using satellite observations of $\mathrm{BrO}$ and ground-based observations (Garbarino et al., 2002; Hollwedel et al., 2004; Lahoutifard et al., 2006; Poulain et al., 2007b; Simpson et al., 2005). During the rest of the year the atmospheric reactions driving the cycling of $\mathrm{Hg}$ in the boundary layer is ambiguous, possibly involving $\mathrm{HO}_{\mathrm{x}}$ and $\mathrm{NO}_{\mathrm{y}}$ radicals (Calvert and Lindberg, 2005; Sommar et al., 2001; Sommar et al., 1997). Therefore, it is important to co-sample $\mathrm{Hg}^{0}$ with other long-lived atmospheric species. Recently, $\mathrm{Hg}^{0} / \mathrm{CO}$ emission ratios from long-distance transported pollution episodes to remote observation sites have been employed to estimate the anthropogenic $\mathrm{Hg}^{0}$ emissions from eastern Asia (Jaffe et al., 2005) and Europe (Slemr et al., 2006) as well as emissions from large scale forest fires (Ebinghaus et al., 2007; Sigler et al., 2003). Selected studies suggest a substantial underestimation of source strength of $\mathrm{Hg}^{0}$ in the current inventories for East Asia and Europe respectively. We have already pointed out that the regimes of $\mathrm{O}_{3}$ are similar with that of $\mathrm{Hg}^{0}$ during MDEs, in addition $\mathrm{O}_{3}$ is produced from degradation of $\mathrm{CO}$ by $\mathrm{OH}$ radicals, so the addition of $\mathrm{O}_{3}$ measurements to the sampling programme was a matter of course.

A main objective was to estimate the spread of mercury in the Arctic environment and to investigate the lability of the deposited $\mathrm{Hg}^{\mathrm{II}}$ compounds in condensed phases with respect to reduction. During the polar transect of the Arctic Ocean from Alaska to Spitsbergen, speciated $\mathrm{Hg}$ measurements were performed including gaseous divalent $\mathrm{Hg}$ species (RGM) and $\mathrm{Hg}$ attached to fine particles $(\mathrm{PHg}$ ) in addition to that of $\mathrm{Hg}^{0}, \mathrm{O}_{3}$ and $\mathrm{CO}$. $\mathrm{PHg}$ has turned out to be a regional tracer for combustion in Europe (Wängberg et al., 2003). This paper focuses on the air measurements alone and is a companion paper of those dealing with mercury in sea water (surface and deep-sea), ice, snow, and sediments collected in the Arctic Ocean during the Beringia 2005 expedition (Andersson et al., 2008b; Andersson, 2010). In Andersson et al. (2008b), the measurements of dissolved gaseous mercury (acronym DGM, practically $\sim \mathrm{Hg}^{0}(\mathrm{aq})$ ) in 
Table 1. Information concerning the air sampling protocol onboard IB Oden (4th deck).

\begin{tabular}{lllll}
\hline Species & Freq. & Start (yy-mm-dd hh:mm) & Stop (yy-mm-dd hh:mm) & Instrument \\
\hline $\mathrm{TGM} \mathrm{Hg}^{0}$ & $12 \mathrm{~h}^{-1}$ & 05-07-05 14:20 & $05-09-24$ 11:00 & Tekran 2537A CVAFS \\
${\mathrm{RGM}-\mathrm{PHg}^{\mathrm{a}}}^{\mathrm{a}}$ & $4 \mathrm{day}^{-1}$ & $05-08-2516: 00$ & $05-09-2217: 00$ & Front sampler+Tekran 2537A CVAFS \\
$\mathrm{O}_{3}$ & $6 \mathrm{~h}^{-1}$ & $05-07-0512: 10$ & $05-09-2212: 00$ & $\mathrm{O}_{3}$ 41M Ansyco Environnement \\
$\mathrm{CO}$ & $120 \mathrm{~h}^{-1}$ & $05-07-0610: 00$ & $05-09-2416: 20$ & AL 5001 AeroLaser \\
\hline
\end{tabular}

${ }^{a}$ Front-sampler used during Leg 3.

the surface waters of the Arctic Ocean are thoroughly described. The DGM data reported will be capitalized on here in connection with the discussion of elevated $\mathrm{Hg}^{0}$ observations in air. Elevated DGM concentrations observed in the surface water of the Arctic Ocean compared to adjacent oceans is presumably due to input by springtime MDEs and large riverine inputs of $\mathrm{Hg}^{\mathrm{II}}$ and dissolved organic carbon (DOC) forming photo-labile complexes as well as limited gas exchange with air due to the sea ice cover (Andersson et al., 2008b). Poulain et al. (2007a) demonstrated the continuous presence of active, cold resistant $\mathrm{Hg}$ reducing microbes in the Arctic Ocean, which do not depend on light. Based on relatively flat vertical profiles of total mercury (Hg-tot) from the Beaufort Sea and the Canadian Archipelago during summer, Outridge et al. (2008) suggested relative minor input from the atmosphere to the Arctic Ocean. St Louis et al. (2007) reported high levels of DGM $\left(129 \pm 36 \mathrm{ng} \mathrm{m}^{-3}\right)$ and organo-mercurials in the surface waters near the Ellesmere Island during late spring.

\section{Experimental}

\subsection{Sampling location}

The measurements were conducted on board the icebreaker Oden. The IB Oden is a $108 \mathrm{~m}$ long and $31 \mathrm{~m}$ wide icebreaker, which has been rebuild to meet scientific demands. The ship is equipped with meteorological and oceanographic instrumentation. The cruise (track outlined in Fig. 1) was divided into three legs: 1. Göteborg, Sweden - Barrow, Alaska, 2. Barrow - Chukchi Peninsula - Wrangel Island - Barrow, 3. Barrow - Longyearbyen, Spitsbergen. Ambient air samples were continuously collected and analyzed using automatic instruments. The instruments were housed in a heated container laboratory at the 4 th deck fronting the stem $(\sim 20 \mathrm{~m}$ above sea level). Further information is summarised in Table 1.

\subsection{Mercury measurements}

A Tekran ${ }^{\circledR}$ (Model 2537A) gas-phase mercury vapour analyzer instrument was used to measure total gaseous mercury (TGM). TGM refers to gaseous elemental mercury $\left(\mathrm{Hg}^{0}\right)$ and

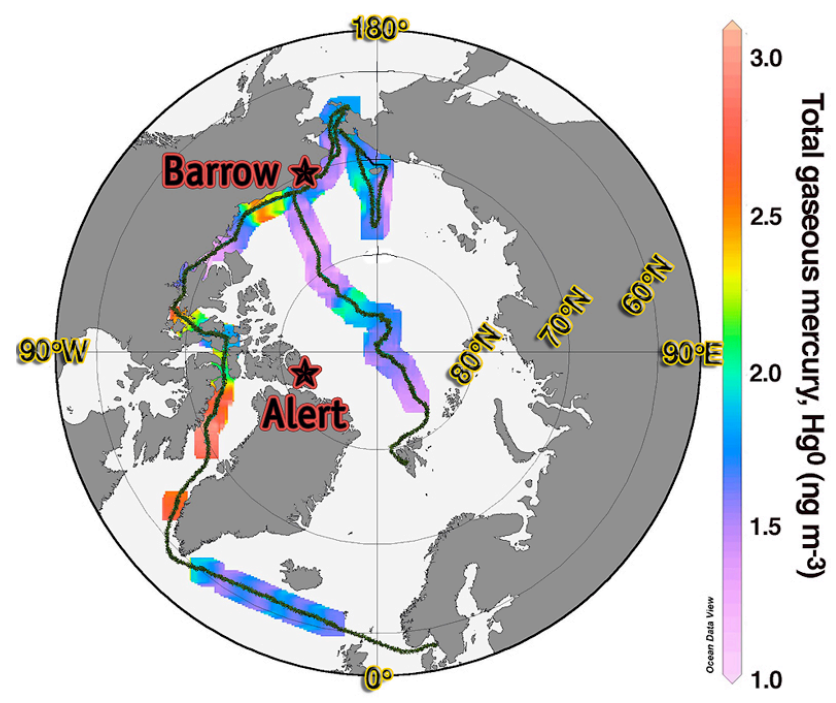

Fig. 1. The spatial distribution of $\mathrm{TGM}, \mathrm{Hg}^{0}$ in air $\left(\mathrm{ng} \mathrm{m}^{-3}\right)$ along the cruise track. The locations of coastal stations Alert (Nunavut, Canada) and Barrow (Alaska, USA) are included as well.

small contributions of other gaseous mercury species $(<1 \%$ at ambient conditions) that may pass through the sampling line and be detected as $\mathrm{Hg}^{0}$ (Temme et al., 2003). The instrument utilised two gold cartridges in parallel, with alternating operation modes (sampling and desorbing/analysing in mercury free Ar stream) on a predefined time base of 5 min. A $0.45 \mu \mathrm{m}$ Teflon filter protected the sampling cartridges against contamination by particulate matter. Ambient air was sampled with a flow rate of $1.5 \mathrm{~L} \mathrm{~min}^{-1}$. The exposure to marine air tends to permanently passivate the gold cartridges. Therefore, the cartridges were changed frequently. To regenerate the cartridges, they were ultrasonically cleaned in a Labosol ${ }^{\circledR}$ wash, repeatedly rinsed with Milli-Q water and dried in a mercury free stream of argon. The performance of the cartridges was routinely checked by injections from internal and external temperature controlled mercury sources. All concentrations are calculated to represent mass of $\mathrm{Hg}^{0}$ per $\mathrm{m}^{3}$ of air at STP $\left(0^{\circ} \mathrm{C}\right.$ and $\left.1013 \mathrm{hPa}\right)$. The method detection limit was $<0.15 \mathrm{ng} \mathrm{m}^{-3}$ for a $5 \mathrm{~min}$ sample calculated as $1 \times \sigma$. 
During the 3rd leg of the Beringia 2005 expedition, an automatic set-up was used to simultaneously measure RGM and PHg (Wängberg et al., 2008). The air to be sampled was pulled through a specially designed intake consisting of a Teflon coated elutriator with an acceleration jet with $2.5 \mu \mathrm{m}$ cut-off and then into a $20 \mathrm{~cm}$ long $\mathrm{KCl}$ coated annular quartz glass denuder (URG-2000-30 K and URG-2000-30CD, University Research Glass Corp, Chapel Hill, NC, USA). A filter holder (made from quartz glass) was placed vertically downstream the $\mathrm{KCl}$ denuder. Fine particles $(\leq 2.5 \mu \mathrm{m})$ were collected on a quartz glass fibre filter of $20 \mathrm{~mm}$ diameter. The denuder and the particle filter were placed in separate ovens followed by a pyrolyser unit kept at $750^{\circ} \mathrm{C}$. The apparatus was assembled in a temperature controlled aluminium box fixed to the gun wale. The sample intake was located in the bottom of the aluminium box $\sim 20 \mathrm{~m}$ above sea level. The denuder was kept at $50^{\circ} \mathrm{C}$ during sampling to protect the $\mathrm{KCl}$ coating from humidity. During analysis both the denuder and quartz filter were purged with mercury-free air. During the initial step of the analysis the particle filter was heated to $600^{\circ} \mathrm{C}$. PHg on the trap was desorbed and thermo-reduced to $\mathrm{Hg}^{0}$ when passing the pyrolyser. In the next step, while the particle trap was maintained at high temperature, the denuder was heated to $540^{\circ} \mathrm{C}$. At $500^{\circ} \mathrm{C}$, RGM was desorbed from the KCl-matrix and totally decomposed to $\mathrm{Hg}^{0}$ in the pyrolyser. The desorbed $\mathrm{Hg}^{0}$ pulses were transferred via a thermally insulated FEP tubing temperature controlled at $60^{\circ} \mathrm{C}$ to the Tekran ${ }^{\circledR}$ instrument (described above) for mercury detection. RGM and PHg samples were collected with a flow rate of $8.5 \mathrm{~L} \mathrm{~min}^{-1}$ during $5 \mathrm{~h}$ effective sampling time with an intervening period of $1 \mathrm{~h}$ for analysis. The method detection limit (MDL) of RGM and PHg were 3 and $1.5 \mathrm{pg} \mathrm{m}^{-3}$, respectively, calculated as $1 \times \sigma$.

In the following, no distinction will be made between the TGM and $\mathrm{Hg}^{0}(\mathrm{~g})$ measurements performed. The acronym $\mathrm{TGM}, \mathrm{Hg}^{0}$ used below is justified by comparing the precision of the Tekran instrument with the actual concentrations of RGM and PHg measured.

Measurement of DGM in surface water as thoroughly described in Andersson et al. (2008b) was performed using a automatic continuous equilibrium system with $10 \mathrm{~min}$ resolution (Andersson et al., 2008c)

\subsection{Ozone and carbon monoxide measurements}

Surface level $\mathrm{O}_{3}$ mixing ratios were measured continuously using a commercial analyzer based on UV absorption $\left(\mathrm{O}_{3} 41 \mathrm{M}\right.$, Ansyco $\mathrm{GmbH}$, Karlsruhe, Germany). The same instrument has been used before during cruises on the Atlantic and Arctic Oceans (Jacobi and Schrems, 1999; Jacobi et al., 2006). It was operated with an integration time of $10 \mathrm{~min}$. Calibrations were made on a daily basis using an internal ozone generator. The detection limit was $1 \mathrm{ppbV}$ at a sampling rate of $1 \mathrm{~L} \mathrm{~min}^{-1}$.
CO mixing ratios were determined also using a commercial detector employing a vacuum-UV resonance fluorescence technique (AL 5001, Aero-Laser GmbH, GarmischPartenkirchen, Germany). Details of the instrument can be found elsewhere (Gerbig et al., 1999). Air samples were collected with a time resolution of $0.5 \mathrm{~min}$. The instrument was calibrated daily using a certified $\mathrm{CO} /$ synthetic air mixture from cylinders. For zero measurements, ambient air was used after removal of $\mathrm{CO}$ by oxidation with Pd-catalyst $\left(150^{\circ} \mathrm{C}\right)$. The detection limit was $<1 \mathrm{ppbV}$. The air inlet (FEP tubing, $10 \mathrm{~m}$ long) for both instruments was positioned in a protective housing (PFA material, Savillex Corp.) in the top of a pylon located $3 \mathrm{~m}$ above the 4 th deck (approximately $22 \mathrm{~m}$ above sea level).

\subsection{Ancillary data}

Meteorological and basic seawater parameters were measured by the ship's monitoring system. The air parameters were measured $30 \mathrm{~m}$ above the sea surface while the aquatic parameters were obtained from the bow-water intake located approximately $5 \mathrm{~m}$ beneath the sea surface.

Air parcel backward trajectories were calculated and converted to GIS line shape files using the TrajStat software (v. 1.1, Wang et al., 2009). A trajectory calculation module of Hybrid Single-Particle Lagrangian Integrated Trajectory (HYSPLIT) Model (Draxler and Rolph, 2003) included in TrajStat as an external process was using gridded meteorological data sets as input. These sets were retrieved from Global Data Assimilation System (GDAS) meteorological data archives (ftp://arlftp.arlhq.noaa.gov/pub/archives/ gdas1/) of the Air Resource Laboratory, National Oceanic and Atmospheric Administration (NOAA). Five-day backtrajectories arriving at 100-1500 $\mathrm{m}$ above sea level were generated every $6 \mathrm{~h}$ along the entire cruise track. The stability was verified by calculating trajectories at different starting heights. Selected trajectory shape files are depicted in Figs. 2-4.

Further data for 2005 regarding $\mathrm{CO}$ and $\mathrm{O}_{3}$ measured at the Arctic coastal stations Alert, Canada and Barrow, Alaska are also presented as well as TGM data from Alert. CO data from Barrow were provided by Paul Novelli (NOAA/ESRL, personal communcation, 2009). $\mathrm{O}_{3}$ and TGM data at Alert were provided by Doug Worthy (Environment Canada, personal communication, 2009) and Alexandra Steffen (Environment Canada, personal communication, 2010) respectively. Further data $\left(\mathrm{O}_{3}\right.$ at Barrow and $\mathrm{CO}$ at Alert) were retrieved from the WMO World Data Centre for Greenhouse Gases (gaw.kishou.go.jp/wdcgg.html). All data are available as 1-h averages. 


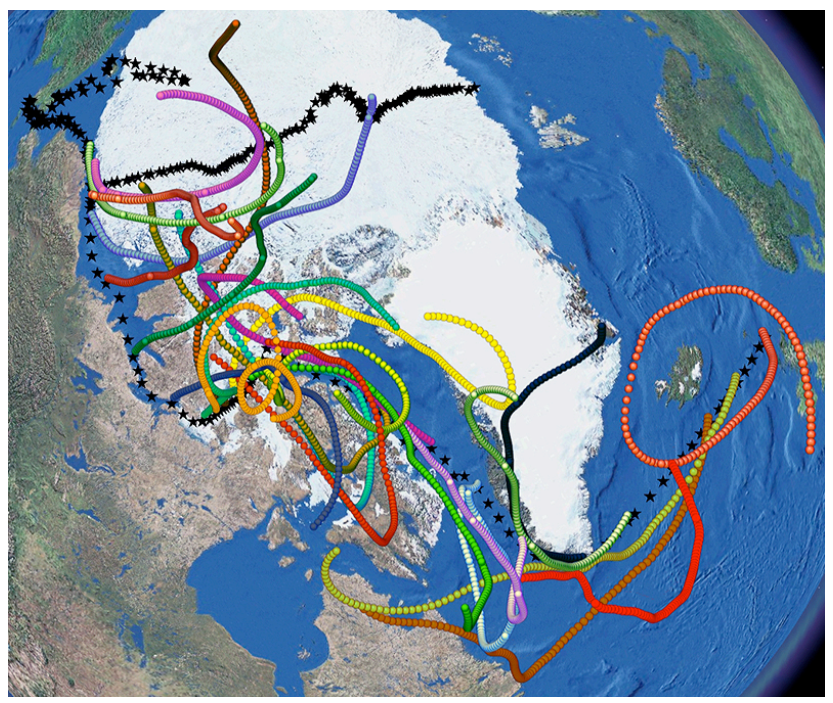

Fig. 2. Cruise track illustrated by ship's position every $6 \mathrm{~h}$ (black stars) and for July plots of selected daily five-day back-trajectories starting (usually at 12:00 UTC) at 100-1500 $\mathrm{m}$ above sea level. The offset in starting elevation was chosen individually to produce a purposeful stable trajectory lacking of significant ground contact. The snow/ice coverage shown in the image does not represent the actual distribution during the cruise.

\subsection{Data analysis}

The raw sampling data of $\mathrm{Hg}^{0} / \mathrm{TGM}, \mathrm{CO}$ and $\mathrm{O}_{3}$ was averaged with a common time base of $10 \mathrm{~min}$. The composite data points were further investigated for abnormal high and/or low concentrations. Using a ship as sampling platform, occasional sampling of the plume of the internal engine is inevitable. It can be expected that in the combustion plume, which contain large amounts of nitrogen oxides and $\mathrm{CO}$, the ratio between $\mathrm{O}_{3}$ and $\mathrm{CO}$ changes significantly due to the consumption of $\mathrm{O}_{3}$ by the following reaction:

$\mathrm{NO}+\mathrm{O}_{3} \rightarrow \mathrm{NO}_{2}+\mathrm{O}_{2}$

Thus, it is handy to screen the data by using the $\mathrm{O}_{3} / \mathrm{CO}$ ratio. Mercury in crude oil is a catalyst's poison and has to be removed before processing the lighter fractions (Wilhelm and Spitz, 2003). However, the heavier fractions used for ship fuel may contain $\mathrm{Hg}$ in the ppb-range (Wilhelm, 2001). It is thus imperative to investigate and possibly screen the $\mathrm{Hg}^{0}$ data to remove values influenced by emissions from the ship (Aspmo et al., 2006; Slemr et al., 1985). These rather frequent local pollution events exhibit an enhanced $\mathrm{CO}$ and low $\mathrm{O}_{3}$ concentration. The exclusion of data points was, therefore, based on crossing a $\mathrm{CO} / \mathrm{O}_{3}$-limit with certain conditions of the two variables and/or by wind direction (see below). To be able to examine the diurnal variability, the data points were lumped into 1-h bins representing the local time instead of UTC. A spatial plot of TGM, $\mathrm{Hg}^{0}$ distribution along the

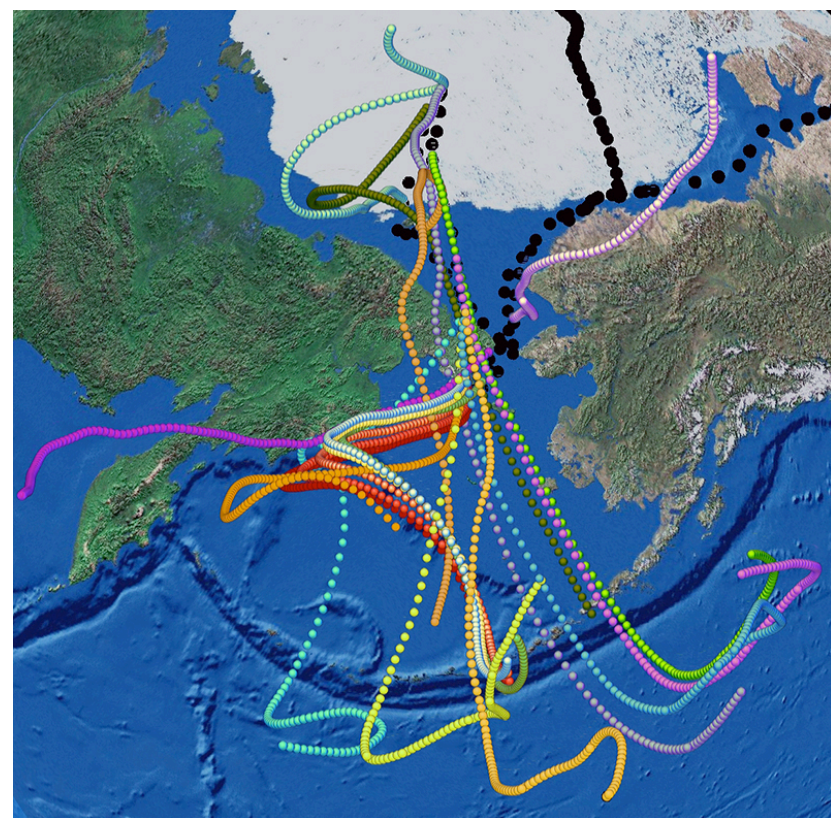

Fig. 3. Cruise track illustrated by ship's position every $6 \mathrm{~h}$ (black dots) and for the two first weeks of August plots of selected fiveday back-trajectories starting at 100-1,800 m above sea level. The offset in starting elevation was chosen individually to produce a purposeful stable trajectory lacking of significant ground contact. Concerning the TGM, $\mathrm{Hg}^{0}$; CO pollution event described in Sect. 3.1.2, trajectories with $6 \mathrm{~h}$ interval starting times are depicted (reddish coloured). The snow/ice coverage shown in the image does not represent the actual distribution during the cruise.

cruise track was generated using Ocean Data View (v. 3.0, Reiner Schlitzer, Alfred Wegener Institute for Polar and Marine Research, Bremerhaven, Germany).

\section{Results and discussion}

\subsection{General observations}

The time series of the concentrations of the trace gases TGM, $\mathrm{Hg}^{0} ; \mathrm{CO}$ and $\mathrm{O}_{3}$ in ambient air samples is shown in Fig. 5. Periods with passage through sea ice are indicated by the blue shading. Figure 6 provides a comparison of the ship-borne trace gas observations with the time series of GAW global stations Alert and Barrow. The spatial distribution of TGM, $\mathrm{Hg}^{0}$ is included in Fig. 1, where the location of Alert and Barrow is indicated. The time series for RGM and PHg during the polar transect (leg 3) is separately displayed in Fig. 7. Only a few PHg concentrations were above MDL, whereas the corresponding fraction for RGM was at $50 \%$. The air samples generally comprised the pristine marine boundary layer (MBL), however, it also include several episodes of local and regional pollution, which has to be taken into consideration. 


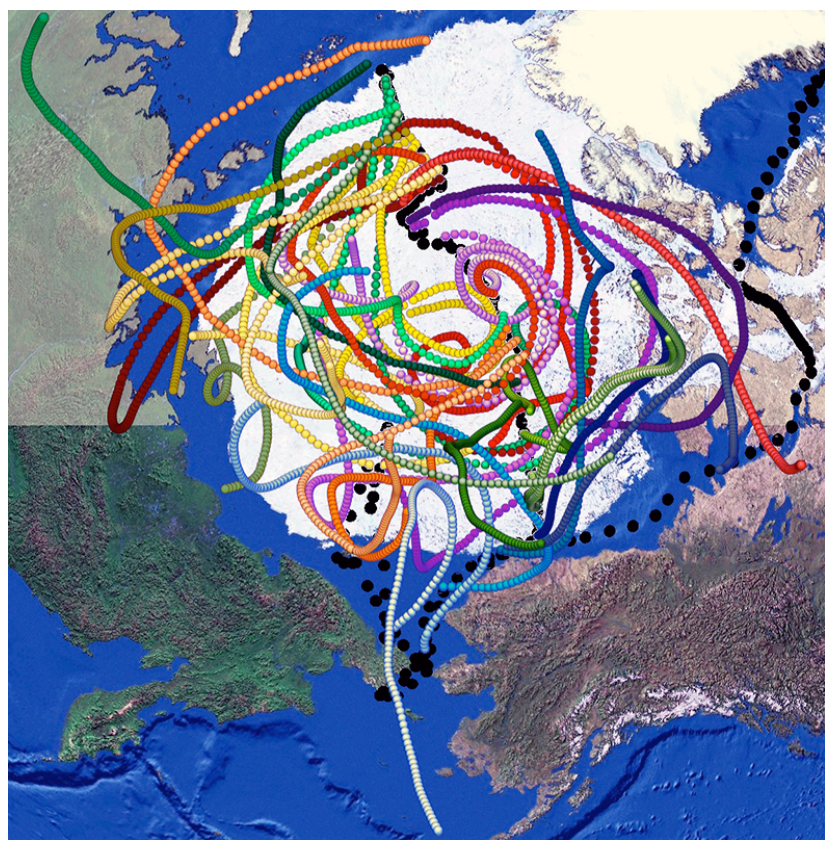

Fig. 4. Cruise track illustrated by ship's position every $6 \mathrm{~h}$ (black dots) and for August (weeks 3-5) and September (weeks 1-3) plots of selected daily five-day back-trajectories starting (usually at 12:00 UTC) at 300-2500 $\mathrm{m}$ above sea level. The offset in starting elevation was chosen individually to produce a purposeful stable trajectory lacking of significant ground contact. The snow/ice coverage shown in the image does not represent the actual distribution during the cruise.

\subsubsection{Pollution from internal combustion}

The local pollution is derived from the plume of the ship's internal combustion engine. The $\mathrm{NO}_{\mathrm{x}}$ - and CO-containing plume titrates $\mathrm{O}_{3}$ by thermal oxidation of $\mathrm{NO}$ (cf. Eq. 1). Hence, when sampling the ship's plume, the $\mathrm{CO} / \mathrm{O}_{3}$-ratio increased significantly (from between 2 and 8 in background air to between 15 and a few hundreds). The sampling artefact occurred concomitantly with wind direction within a sector of $180^{\circ} \pm 60^{\circ}$ relative to the ship's bow or with wind speeds less than $3 \mathrm{~m} \mathrm{~s}^{-1}$. The conceivable impact of the plume on the $\mathrm{Hg}^{0}$-levels measured was examined. For events with $\mathrm{CO}$ to $\mathrm{O}_{3}$ ratios larger than 15 , the corresponding $\mathrm{Hg}^{0} / \mathrm{TGM}$ data was plotted vs. CO (Fig. 8). These parameters were only weakly correlated with no obvious trend. This was also the case for PHg and RGM. Hence, we conclude that the exhaust of the IB Oden does not affect the measurements of the mercury components. During the polar transect, IB Oden navigated in tandem with US-CGC Healy (WAGB-20). Occasionally, the plume from US-CGC Healy was intercepting the sampling intakes, likewise without indicating enhanced mercury levels.
In summary, the screening criteria finally used to reject $\mathrm{CO}$ and $\mathrm{O}_{3}$ data possibly influenced by local pollution are: $[\mathrm{CO}] /\left[\mathrm{O}_{3}\right]>15$ and $\left[\mathrm{O}_{3}\right]<8 \mathrm{ppbV}$. A particular air pollution event on August 5th caused by an approaching bunker ship in open sea provided an elevated signal of TGM, $\mathrm{Hg}^{0}$. In this single case, $\mathrm{Hg}$ data were screened out. In Fig. 5, these screened data can be distinguished as open symbols (red circles for $\mathrm{O}_{3}$ and black squares for $\mathrm{CO}$ respectively).

\subsubsection{Regional pollution}

Some pollution episodes were encountered in a fjord and along the coast of the Chukchi Peninsula. These events during the first week of August are characterised by elevated TGM, $\mathrm{Hg}^{0}$ and $\mathrm{CO}$ mixing ratios at mid-to-low $\mathrm{O}_{3}$ concentrations (10-15 ppbV). Analysis of the corresponding back trajectories demonstrated that the air masses previously slightly passed over the Chukchi Peninsula but essentially had a marine fetch (cf. Fig. 4). The 2-3 August episode occurring in the fjord of Providence Bay was the most extensive one ( $\sim 7 \mathrm{~h}$ duration), where TGM, $\mathrm{Hg}^{0}$ and $\mathrm{CO}$ showed maxima at $\sim 5 \mathrm{ng} \mathrm{m}^{-3}$ and $\sim 225 \mathrm{ppbV}$ $(\sim 420 \mathrm{ppbV}$ at $30 \mathrm{~s}$ resolution) respectively. A close-up TGM-CO scatter plot of this event in Fig. 9 shows a moderate linear correlation (statistically significant at $>95 \%$ confidence). The enhancement of these gases represented by the slope $\Delta\left(\mathrm{TGM}, \mathrm{Hg}^{0}\right) / \Delta \mathrm{CO}$ of $0.016 \mathrm{ng} \mathrm{m}^{-3} \mathrm{ppbV}^{-1}$ $\left(\sim 1.8 \times 10^{-5} \mathrm{~mol} \mathrm{~mol}^{-1}\right)$ is however well above the narrow range of $(0.67-2.4) \times 10^{-7} \mathrm{~mol} \mathrm{~mol}^{-1}$ hitherto reported for biomass burning (Ebinghaus et al., 2007) and also significantly higher than East Asian industrial emission ratios of $\sim(5 \pm 2) \times 10^{-6} \mathrm{~mol} \mathrm{~mol}^{-1}$ reported by Weiss-Penzias et al. (2007). Since TGM, $\mathrm{Hg}^{0}$ and CO were only moderately correlated during this episode, it is probable that the air plume was influenced by the mixing of changing backgrounds or was impacted by multiple sources (cf. Jaffe et al., 2005). Moreover, the mountainous and complex terrain settings (with peaks above $2000 \mathrm{~m}$ ) around the fjord probably influenced the local meteorology and air flow.

\subsection{Observations of Arctic and North Atlantic background air}

After removing data possibly influenced by internal combustion pollution, Table 2 was constructed showing the descriptive statistics of the measurements. The major trace gas data applying to merely the Arctic Ocean are summarized in Table 3. These sampled parameters have furthermore been divided into observations made over sea ice as well as into monthly information. Since the measurements were made during an extended period on a mobile platform covering major parts of the Arctic, they can be influenced by seasonal as well as spatial concentrations patterns. Table 3 also include a statistical summary of TGM observations at station Alert. 


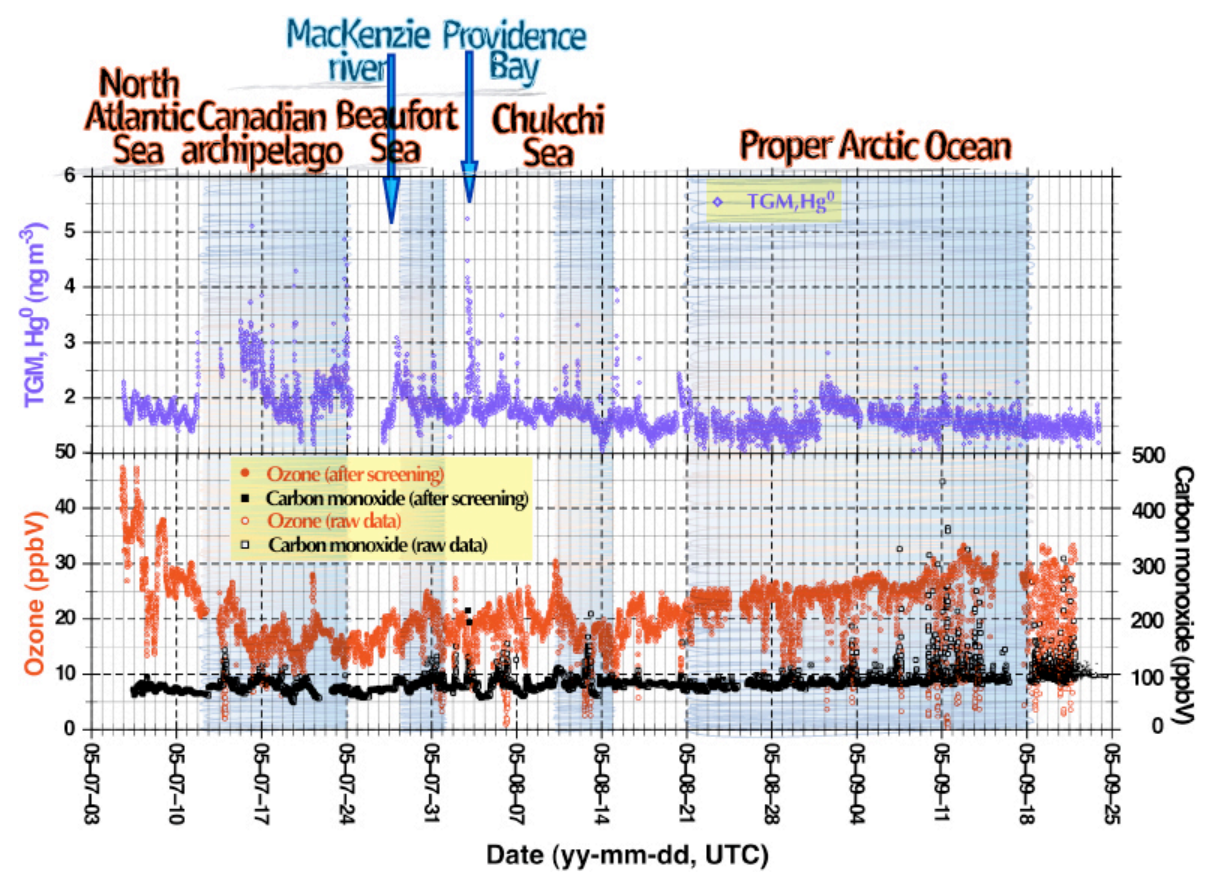

Fig. 5. 10-min averaged concentrations of atmospheric trace gases TGM, $\mathrm{Hg}^{0} ; \mathrm{O}_{3} ; \mathrm{CO}$ over the northern Atlantic and Arctic Ocean measured onboard the IB Oden during BERINGIA 2005. Passage through ice-covered sea is shaded in bluish colours. The names of some important geographical area discernible in Fig. 1 are indicated as well.

Table 2. Summary of the measurements after screening the raw data from local combustion.

\begin{tabular}{llllllll}
\hline Species & $N$ & Mean & Min & Max & Median & SD & RSD \\
\hline${\text { TGM }, \mathrm{Hg}^{0}\left(\mathrm{ng} \mathrm{m}^{-3}\right)}^{-3}$ & 9061 & 1.73 & 1.00 & 5.24 & 1.67 & 0.36 & 0.21 \\
DGM $\left(\mathrm{ng} \mathrm{m}^{-3}\right)$ & 6138 & 42.4 & 4.9 & 207.4 & 37.7 & 25.9 & 0.61 \\
$\mathrm{O}_{3}(\mathrm{ppbV})$ & 9793 & 21.4 & 8.0 & 47.3 & 21.0 & 5.5 & 0.27 \\
$\mathrm{CO}(\mathrm{ppbV})$ & 10000 & 84.4 & 50.3 & 223.8 & 84.0 & 11.6 & 0.14 \\
RGM $\left(\mathrm{pg} \mathrm{m}^{-3}\right)$ & 57 & 3.2 & $0.7(\mathrm{ND})$ & 10.0 & 3.1 & 1.7 & 0.53 \\
PHg $\left(\mathrm{pg} \mathrm{m}^{-3}\right)$ & 54 & 1.0 & $0.2(\mathrm{ND})$ & 3.2 & $0.9(\mathrm{ND})$ & 0.7 & 0.71 \\
\hline
\end{tabular}

Before entering the Canadian Arctic (Labrador Sea into Baffin Bay) measurements represent conditions in the North Atlantic. Accordingly, $\mathrm{O}_{3}$ mixing ratios between 30 and almost $50 \mathrm{ppbV}$ were observed. In the Canadian Arctic, the airflow shifted from having a North Atlantic into a Polar fetch leading to a decrease of $\mathrm{O}_{3}$ to around 15 to $20 \mathrm{ppbV}$ (cf. Fig. 5). The drop in ambient $\mathrm{O}_{3}$ levels may indicate air masses from remote, low- $\mathrm{NO}_{\mathrm{x}}$-environments where more ozone destruction than ozone production occurs during summertime (Helmig et al., 2007). Henceforward, a steady increase in $\mathrm{O}_{3}$ from 20 to $30 \mathrm{ppbV}$ was observed during the 1month long polar transect from the Beaufort Sea to the Barents Sea. Trajectory simulations indicated that air masses were advected from long fetches predominantly within the Canadian and Siberian parts of Arctic Ocean and sometimes extending into continental Eurasia (Fig. 4). Besides these trends in the background $\mathrm{O}_{3}$ concentrations, the time series also indicates numerous short term reductions of $\mathrm{O}_{3}$, when the mixing ratios dropped to 10 to $15 \mathrm{ppbV}$.

Compared to $\mathrm{O}_{3}$ the variability in the $\mathrm{CO}$ mixing ratios was smaller. The average values ranged from around $80 \mathrm{ppbV}$ during the first half of the cruise. During the second half of the expedition, we observed a statistically significant ( $>95 \%$ confidence) linear increase in the CO data (slope: $0.3 \mathrm{ppbV} \mathrm{day}^{-1}, R=0.50$ ), until the values reached an average of around $110 \mathrm{ppbV}$ during the second half of September. Nevertheless, even CO mixing ratios showed a short-term variability in the order of several tens of ppbV.

To distinguish between spatial and seasonal trends, Fig. 6 shows the ship-borne data together with measurements performed at the Arctic coastal stations Alert and Barrow during the same period. On two occasions dated in Fig. 6, IB Oden 
Table 3. Summary of screened TGM, $\mathrm{Hg}^{0} ; \mathrm{O}_{3}$ and $\mathrm{CO}$ data applicable to the Arctic Ocean (incl. Baffin Bay, Northwest Passages, Beaufort Sea, Chukchi Sea, and Greenland Sea). Excluded are thus data from the North Atlantic Ocean, Labrador Sea and Bering Sea (IHO, 1953). Descriptive statistics of TGM data from station Alert on Ellesmere Island are included as well.

\begin{tabular}{|c|c|c|c|c|c|c|c|c|c|c|c|c|c|c|c|c|c|c|c|}
\hline \multirow{2}{*}{ Species } & \multicolumn{4}{|c|}{ Overall } & \multicolumn{3}{|c|}{ July } & \multicolumn{3}{|c|}{ August } & \multicolumn{3}{|c|}{ September } & \multicolumn{3}{|c|}{ Sea Ice } & \multicolumn{3}{|c|}{ Sea w/o ice } \\
\hline & $N$ & Mean & Med. & SD & $N$ & Mean & SD & $N$ & Mean & SD & $N$ & Mean & SD & $N$ & Mean & SD & $N$ & Mean & SD \\
\hline $\begin{array}{l}\text { TGM, Hg }{ }^{0} \\
\left(\mathrm{ng} \mathrm{m}^{-3}\right) \\
\text { IB Oden }\end{array}$ & 7864 & 1.72 & 1.67 & 0.35 & 1737 & 2.08 & 0.44 & 3686 & 1.62 & 0.24 & 2441 & 1.61 & 0.20 & 5443 & 1.81 & 0.41 & 2421 & 1.55 & 0.21 \\
\hline $\begin{array}{l}\text { TGM } \\
\left(\text { ng m }^{-3}\right) \\
\text { Alert }\end{array}$ & 1764 & 1.86 & 1.80 & 0.31 & 580 & 2.08 & 0.24 & 649 & 1.91 & 0.26 & 535 & 1.55 & 0.12 & & & & & & \\
\hline $\mathrm{O}_{3}(\mathrm{ppbV})$ & 8491 & 20.6 & 20.9 & 4.6 & 2435 & 17.3 & 3.1 & 3,859 & 20.4 & 3.4 & 2197 & 24.5 & 4.7 & 5921 & 21.1 & 4.8 & 2570 & 19.4 & 3.9 \\
\hline $\mathrm{CO}(\mathrm{ppbV})$ & 9276 & 87.0 & 85.6 & 11.8 & 2396 & 80.9 & 11.2 & 4060 & 84.3 & 9.4 & 2820 & 96.2 & 9.9 & 6215 & 87.3 & 10.4 & 3061 & 86.5 & 14.3 \\
\hline
\end{tabular}

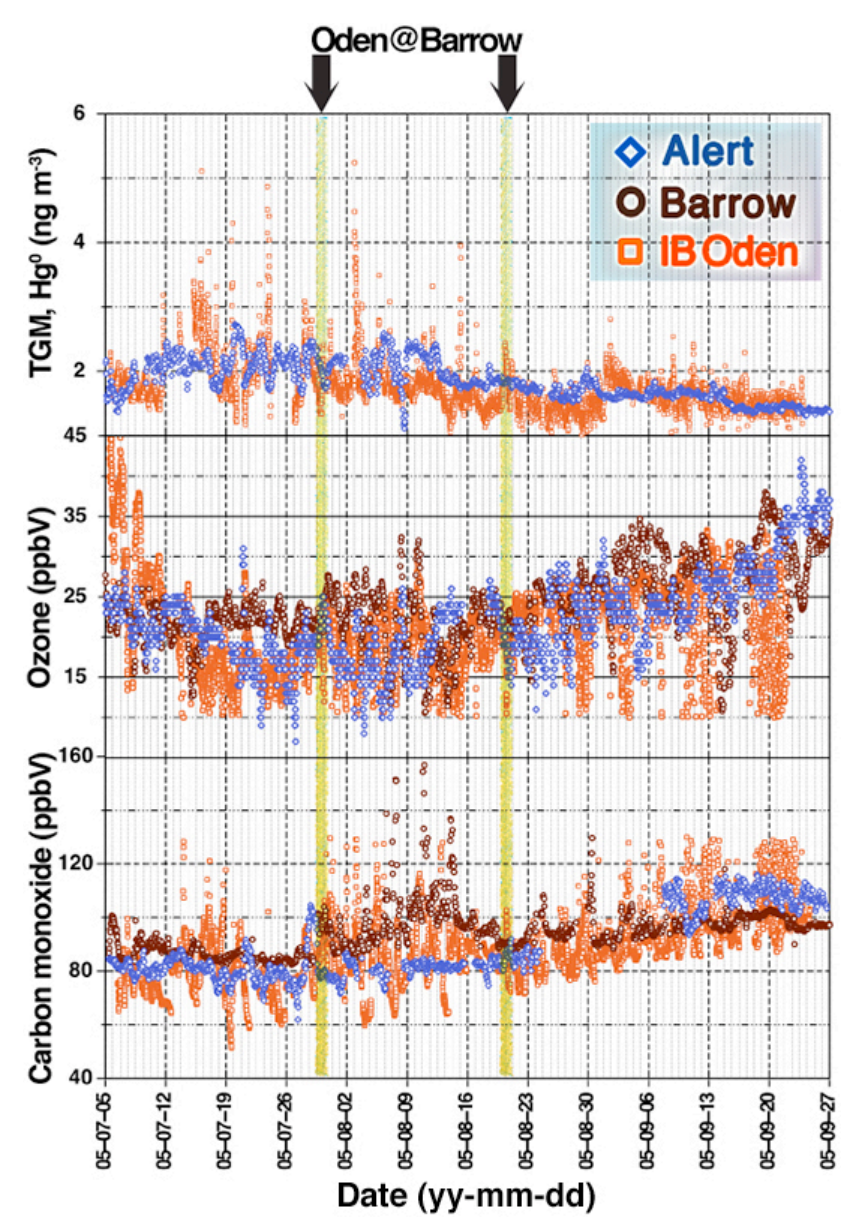

Fig. 6. Comparison of Oden (orange squares), Barrow (brown circles) and Alert (blue diamonds) observations for TGM, $\mathrm{Hg}^{0}$ (upper panel), $\mathrm{O}_{3}$ (middle panel) and for $\mathrm{CO}$ (lower panel). The time series from IB Oden depicted are comprised of 10-min averaged data while the others refer to hourly averaged data. Periods shaded in yellow resemble anchorage time of IB Oden outside Pt. Barrow.

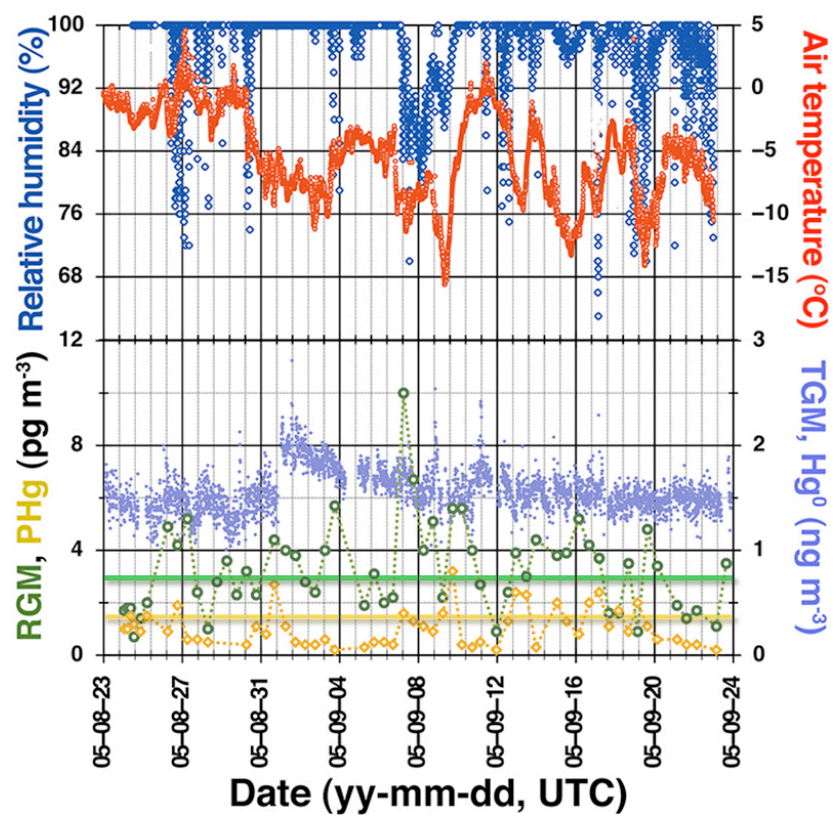

Fig. 7. Concentrations of airborne speciated mercury (TGM, $\mathrm{Hg}^{0}$; RGM and PHg, in lower panel) and some air parameters (temperature and relative humidity, in upper panel) measured along the transpolar route. Drawing the detection limits for RGM (green line) and $\mathrm{PHg}$ (yellow line) indicate the sampling data points below MDL.

anchored in the roadstead outside Barrow whereas Oden and Alert were separated by a shortest distance of $\sim 800 \mathrm{~km}$ during the cruise. Obviously, several of the trends in $\mathrm{O}_{3}$ and $\mathrm{CO}$ concentrations are observed at the coastal stations as well as onboard. This concerns for example the relatively low values for $\mathrm{O}_{3}$ and $\mathrm{CO}$ in July and August and the subsequent increase beginning in the second half of August. We conclude that the observed seasonal cycles of $\mathrm{O}_{3}$ as well as $\mathrm{CO}$ are not restricted to the coastal sites, but also exist over the Arctic Ocean. Therefore, we suggest that the observations at Arctic coastal stations regarding $\mathrm{O}_{3}$ and $\mathrm{CO}$ between July and September can be considered as representative for the 


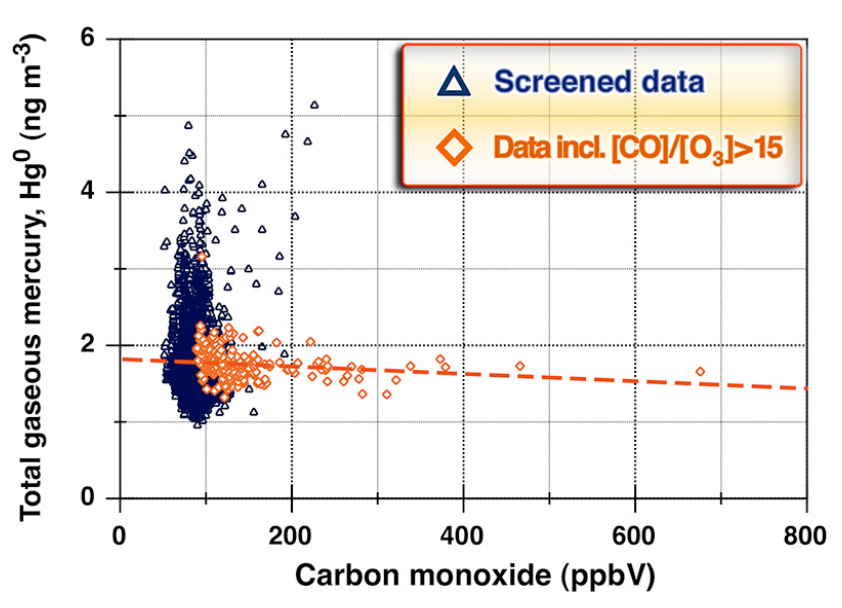

Fig. 8. The relationship between $\mathrm{TGM}, \mathrm{Hg}^{0}$ and $\mathrm{CO}$ during events of pollution from the ship's internal engine determined by a ratio of $[\mathrm{CO}] /\left[\mathrm{O}_{3}\right]$ larger than 15 (diamonds). Also included are the data screened according to Sect. 3.1.1 (triangles) but not comprised in the linear regression fit. The parameters are only weakly correlated implying that the ship's emissions are negligible with respect to $\mathrm{Hg}$.

entire Arctic. Such a homogeneous distribution is also in good agreement with the relatively long chemical lifetimes of $\mathrm{O}_{3}$ and $\mathrm{CO}$ (between weeks and months, Helmig et al., 2007; Novelli et al., 1998) compared to average transport times into the Arctic of several days in summertime (Stohl, 2006).

The largest discrepancies between the Arctic coastal stations and the ship borne measurements in the long-term trends were observed for $\mathrm{O}_{3}$ at the beginning of the cruise. This clearly indicates the influence of the North Atlantic air masses during this part of the cruise, which contribute to elevated $\mathrm{O}_{3}$ mixing ratios compared to the Arctic. Interestingly, these air masses have no effect on the $\mathrm{CO}$ mixing ratios, which appear not to be lower over the Arctic Ocean compared to the North Atlantic.

The short-term variability in $\mathrm{O}_{3}$ and $\mathrm{CO}$ as observed in the ship borne measurements were in the case of $\mathrm{O}_{3}$ also apparent at the coastal stations. They might be to some extent obscured in the coastal $\mathrm{CO}$ data due to the longer averaging into $1-\mathrm{h}$ averages compared to the 10-min averages collected onboard. Nevertheless, these short-term fluctuations are probably related to pollution events caused by continental sources (Novelli et al., 1998). It is interesting to note, that such pollution events were also observed in the second half of the cruise over the Arctic Ocean at relatively long distances from potential continental sources (Fig. 4). By contrast to the observations made in the Beringia region, these events exhibit a general lack of correlation between TGM, $\mathrm{Hg}^{0}$ and CO.

By comparison with summer observations (median: $1.67 \mathrm{ng} \mathrm{m}^{-3}$, July-September) from Alert, 1995-2002, Oden TGM, $\mathrm{Hg}^{0}$ data exhibit an equivalent statistical median (Stef-

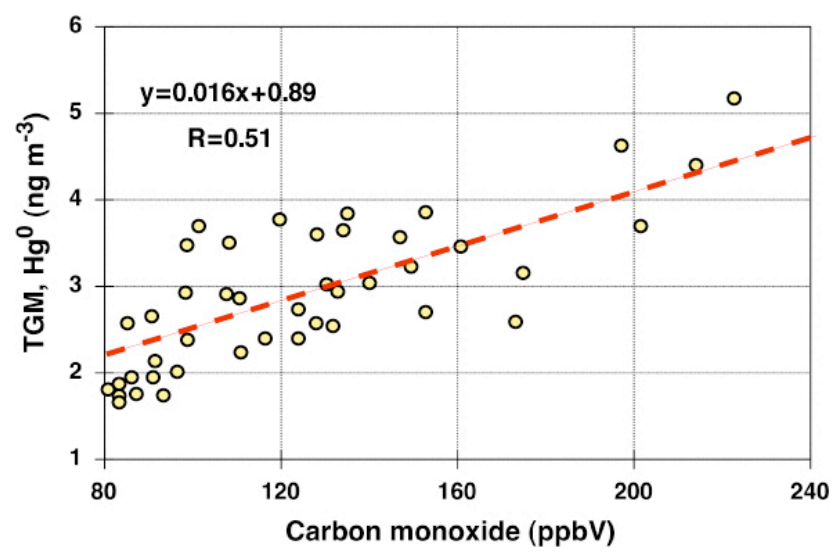

Fig. 9. Scatterplot of TGM, $\mathrm{Hg}^{0}$ vs. CO observations during the 2-3 August pollution episode. The equation of the linear fit as well as the correlation coefficient are displayed.

fen et al. 2005). Decadal observations at Alert between 1995 and 2005 reveal no perennial statistically significant trend for the summer period. Analogous to Alert 2005 summer data, the magnitude of and variability in the Arctic MBL TGM, $\mathrm{Hg}^{0}$ concentrations as observed onboard Oden were largest during the early phase of the season (Fig. 6). The variability in the latter data set is obviously higher, however the corresponding statistical means compare very favourably and are significantly higher (at $>99 \%$ confidence level) than that of the North Atlantic observations (mean: $1.73 \mathrm{ng} \mathrm{m}^{-3}$ ). Upon entering the Canadian Arctic, the swift shift in ambient $\mathrm{TGM}, \mathrm{Hg}^{0}$ level qualitatively represents the reciprocal behaviour of $\mathrm{O}_{3}$. The increased concentration of TGM, $\mathrm{Hg}^{0}$ observed in the early summer Arctic MBL is thus not caused by advection of polluted mid-latitudinal air masses but is according to back-trajectory analysis due to sources present in the Arctic basin. In a modelling study of bidirectional surface exchange in the Arctic, Dastoor et al. (2008) predicted that only in July a net re-emission of mercury prevails (averaged for years 2002-2004). Trajectory analysis for $\mathrm{Hg}^{0}$ measurements at Zeppelin station during 2000-2008 indicates that the Arctic Ocean acts a source of $\mathrm{Hg}^{0}$ to the atmosphere in July and August (Hirdman et al., 2009). In Table 3 , the observed average $\mathrm{TGM}, \mathrm{Hg}^{0}$ concentration has been binned spatially into measurements over open sea and over sea ice (partial and total coverage, shaded in Fig. 6), respectively. The mean concentration of the first classification $\left(1.55 \pm 0.21 \mathrm{ng} \mathrm{m}^{-3}\right)$ was lower (heteroscedastic t-test, $p<0.01)$ than that of the second $\left(1.81 \pm 0.41 \mathrm{ng} \mathrm{m}^{-3}\right)$. Also apparent in Table 3 is that no significant divergent distribution between ice and open water was observed for either $\mathrm{O}_{3}$ or $\mathrm{CO}$. This agrees with the homogeneous distribution of both compounds between the Arctic Ocean and the coastal stations, which is mainly governed by large-scale transport and chemical processing in the atmosphere. However, concerning the corresponding DGM data, there was a 


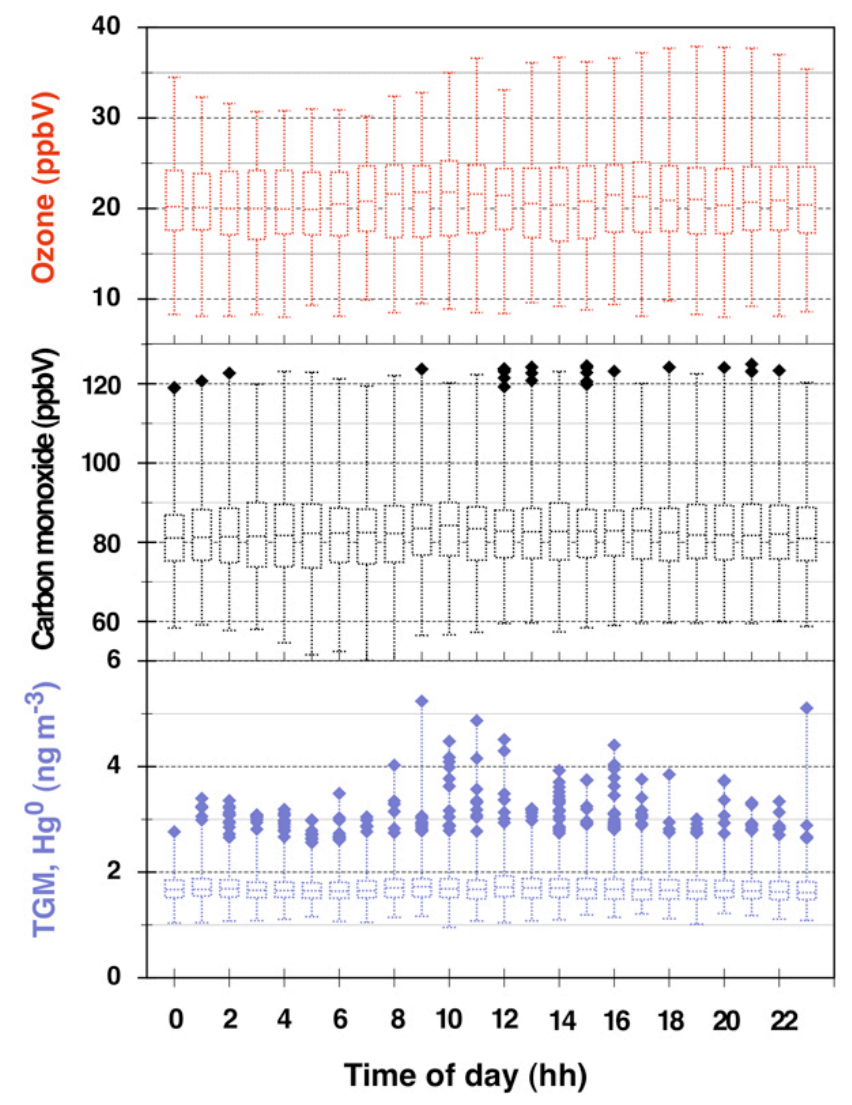

Fig. 10. Diurnal variations of the $\mathrm{O}_{3}, \mathrm{CO}$ and $\mathrm{TGM}, \mathrm{Hg}^{0}$ concentrations summarised as in Table 2. The box assemblies include the mean, the upper and lower $95 \%$ confidence intervals and extremes (far outliers) for 1-h per bin diurnally integrated samples. The UTC time data has been recalculated to represent destination local time.

more striking difference between the averages of the two data bins (not shown in Table 3, see Andersson et al., 2008b). Our TGM, $\mathrm{Hg}^{0}$ data set compares well with that of Aspmo et al. (2006) concerning higher TGM, $\mathrm{Hg}^{0}$ concentrations over ice covered areas. The study by Aspmo et al. (2006) covering North Atlantic latitudes $54-85^{\circ}$ in summer (June-August), where a step in ambient $\mathrm{Hg}^{0}$ concentration occurred at $82^{\circ} \mathrm{N}$ when entering an area with elevated sea ice concentration. In the present study, the corresponding transition in the TGM, $\mathrm{Hg}^{0}$ level was encountered in the Baffin Bay $\sim 70^{\circ} \mathrm{N}$. The study by Aspmo et al. (2006) also included measurements of airborne oxidised mercury (RGM and PHg). Jointly, low concentrations of RGM and PHg were measured. In Table 2, the RGM and PHg data tabulated include the observations below MDL. Replacing the values below MDL with a constant value of MDL/2 does not influence the overall statistics.

In Fig. 10, the diurnal variability of $\mathrm{CO}, \mathrm{O}_{3}$ and TGM, $\mathrm{Hg}^{0}$ mixing ratios are shown in terms of box plots. The day length during air sampling was at least $22 \mathrm{~h}$. In fact, more than $90 \%$ of the data was obtained during mid-night sun. No overall distinct diurnal pattern is discernible for ei-
Table 4. Over-all correlation matrix of trace gases and DGM.

\begin{tabular}{lllll}
\hline Species & TGM, $\mathrm{Hg}^{0}$ & DGM & $\mathrm{O}_{3}$ & $\mathrm{CO}$ \\
\hline TGM, $\mathrm{Hg}^{0}$ & & & & \\
DGM & -0.035 & & & \\
$\mathrm{O}_{3}$ & -0.266 & -0.027 & & \\
$\mathrm{CO}$ & -0.086 & 0.155 & 0.036 & \\
\hline
\end{tabular}

ther $\mathrm{CO}, \mathrm{O}_{3}, \mathrm{TGM}, \mathrm{Hg}^{0}$ or the transient mercury fractions RGM and PHg (not displayed). In general, diurnal cycles of $\mathrm{O}_{3}$ are small in polar regions (amplitude range $0-1.5 \mathrm{ppbV}$ ) and expected to decline with increasing latitude (Helmig et al., 2007). In contrast, during five consecutive days of the initial Atlantic transect diurnal features were observed for TGM (cf. Figs. 1 and 5). Such diurnal variations in TGM have previously been reported from ship-based measurements in more temperate latitudes of the northern hemisphere and explained to a large extent be accounted by $\mathrm{Hg}^{0}$ evasion from surface water (Laurier et al., 2003). Strongly modulated features in TGM, $\mathrm{Hg}^{0}$ were in the present study, however, above all confined to events with elevated DGM or as been reported in Sect. 3.1.2 to regional pollution events encountered at the Chukchi Peninsula. The former episodes of considerable interest for this study will be further investigated and discussed below.

\subsubsection{The role of air-sea exchange of $\mathrm{Hg}^{\mathbf{0}}$ in the measured atmospheric $\mathrm{Hg}^{\mathbf{0}}$ /TGM concentrations}

Table 4 shows the correlation matrix for the major trace gases measured including the dissolved gaseous mercury (DGM) in the surface water (Andersson et al., 2008b). All parameters were found to be only weakly inter-correlated. Furthermore, lagged cross-correlation analysis was applied on the subsets of the TGM, $\mathrm{Hg}^{0}$-DGM data involving periods of a high variability in both variables with high supersaturation of $\mathrm{Hg}^{0}$ in the sea (such as the passage through certain parts of the Canadian archipelago, the discharge zone of Mackenzie river and the Arctic Ocean at $\sim 86^{\circ} \mathrm{N}$, cf. Fig. 11). By moving TGM, $\mathrm{Hg}^{0}$ towards increasing time domain (typically $2-3 \mathrm{~h}$ ), a significant improvement in the correlation from overall $R=-0.035$ to $R \sim 0.4-0.6$ was obtained for several periods. In Fig. 11, the TGM, $\mathrm{Hg}^{0}$-DGM data are plotted together with time lags of 2 and $2.5 \mathrm{~h}$ for two episodes from different legs of the expedition. The physical rationale for a time delay in the $\mathrm{TGM}, \mathrm{Hg}^{0}$ signal is mass transport limitation in the sea-air transfer of the ensued strong supersaturation of DGM (the degree of supersaturation of DGM in the surface sea water $(\%)$ can be calculated according to: $S=\left(\mathrm{DGM} \times k_{\mathrm{H}} /\left(\mathrm{TGM}, \mathrm{Hg}^{0}\right)-1\right) \times 100$, where $k_{\mathrm{H}}$ is the dimensionless Henry's law constant determined e.g. by Andersson et al., 2008a). For a sparingly soluble gas like $\mathrm{Hg}^{0}(\mathrm{~g})$ 
the hydrodynamic barrier delaying the increasing DGM levels to be propagated into the air. The cases presented refer to a partially open sea (Fig. 11a) and an icebound sea (Fig. 11b). In the ice-covered oceanic surface waters such as in Fig. 11b, it is likely that elevated DGM concentrations were built up due to the restricted air exchange (Andersson et al., 2008b). On the other hand, the formation rate of DGM is dependant on biotic and abiotic reduction of $\mathrm{Hg}^{\mathrm{II}}(\mathrm{aq})$ and a cap of seaice will attenuate photoreduction and retard DGM formation. The headway of IB Oden including the ice breaking presumably influences the gas-exchange of $\mathrm{Hg}^{0}$ positively.

The future predictions for the cycling of mercury in the Arctic are coupled with changes in the climate system. The global warming has and will have a profound and extensive impact on the biogeochemical cycle of $\mathrm{Hg}$ in the polar regions. The minimum sea ice extent of the Arctic Ocean has decreased at an average of $(-7.4 \pm 2.4) \%$ per decade since 1979 while the corresponding decrease of mean annual extent of Arctic sea-ice is only at $(-2.7 \pm 0.6) \%$ per decade (Lemke et al., 2007). Simulations indicate abrupt future reduction reaching near ice-free September conditions by 2040 (Holland et al., 2006). As climate warming presumably will initially influence the magnitude and spatial extent of Arctic MDEs and boost photo-reduction of $\mathrm{Hg}^{\mathrm{II}}(\mathrm{aq})$ the efflux of $\mathrm{Hg}^{0}$ from the Arctic Ocean to the atmosphere during summer is predicted to rapidly increase in the near future. The TGM, $\mathrm{Hg}^{0}$-DGM observations made in this study over the Arctic Ocean going from $60^{\circ}$ to $90^{\circ} \mathrm{N}$ indicate that elevated concentrations are not only restricted to circumpolar marginal seas but also apply to the proper Arctic Ocean. Using a model developed by Nightingale et al. (2000), Andersson et al. (2008b) calculated a hypothetical average $\mathrm{Hg}^{0}$ evasion of $\sim 60 \mathrm{ng} \mathrm{m}^{-2}$ day $^{-1}$ during the Beringia 2005 expedition with a maximum as high as $\sim 2300 \mathrm{ng} \mathrm{m}^{-2} \mathrm{day}^{-1}$. St Louis et al. (2007) calculated a $\mathrm{Hg}^{0}$ flux of $130 \pm 30 \mathrm{ng} \mathrm{m}^{-2}$ day $^{-1}$ at ice break-up. In-turn Outridge et al. (2008) predict a 8-fold increase in summer $\mathrm{Hg}^{0}$ flux for the future between $60^{\circ} \mathrm{N}$ and $80-90^{\circ} \mathrm{N}$. The average $\mathrm{Hg}$ turnover time for the upper Arctic Ocean, which is at present $\sim 5$ years, may thus decrease.

\subsubsection{The oxidation capacity of the Arctic MBL during summer}

The low $\mathrm{O}_{3}$ concentrations in July and August agree well with the analysis of air mass transport from the Arctic Ocean to a coastal site in the Arctic (Hirdman et al., 2009). The detailed trajectory analysis for $\mathrm{O}_{3}$ measurements at Zeppelin station indicates that the Arctic Ocean constitutes a sink for $\mathrm{O}_{3}$ in spring- and summertime. While the destruction of $\mathrm{O}_{3}$ in April and May is related to ozone depletion events (ODEs) leading to the complete removal of $\mathrm{O}_{3}$ in the MBL (Simpson et al., 2007), the lower $\mathrm{O}_{3}$ concentrations in summer may be due to a combination of processes. The chemical destruction of $\mathrm{O}_{3}$ as a result of halogen activation from the abundant sea
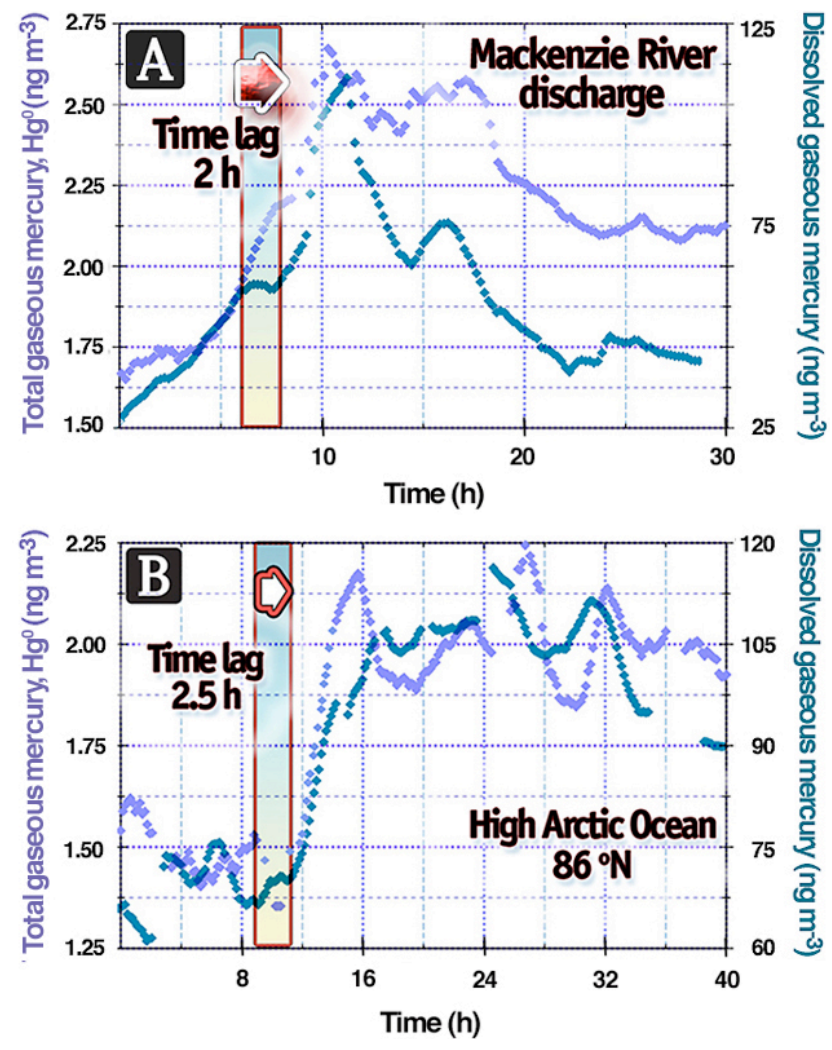

Fig. 11. The temporal air-sea distribution of $\mathrm{Hg}^{0}$ vapour for two specific destinations: (a) Mackenzie River discharge and (b) high Arctic Ocean $\left(\sim 86^{\circ} \mathrm{N}\right)$. Cross-correlation analysis revealed a maximised TGM, $\mathrm{Hg}^{0}$-DGM covariance for time lags of $2 \mathrm{~h}$ and $2.5 \mathrm{~h}$, respectively. Thus, the time-series of TGM, $\mathrm{Hg}^{0}$ and DGM has been shifted in (a) by $2 \mathrm{~h}$ and in (b) by $2.5 \mathrm{~h}$. The maximum coefficient of correlation is $0.59(n=188)$ in case a and $0.54(n=307)$ in case b. The distribution of $\mathrm{Hg}^{0}$ between air and sea is in both cases in strong disequilibrium.

salt can continue, although it is necessarily less effective than in springtime since no ODEs have yet been observed in summer (Simpson et al., 2007). The low $\mathrm{NO}_{\mathrm{x}}$-environment like the Arctic can also contribute to a more efficient chemical $\mathrm{O}_{3}$ destruction during summer (Helmig et al., 2007). Both processes are related to the levels of incoming solar radiation, which start to decrease in late summer in the high latitudes. In addition, a more effective deposition to the open water areas compared to the snow-covered sea ice can reduce the $\mathrm{O}_{3}$ concentrations in the MBL (e.g. Gallagher et al., 2001; Helmig et al., 2009). In contrast, the absence of any significant diurnal variability for $\mathrm{O}_{3}$ indicates that in situ photochemical production in the Arctic MBL is low during this period of time.

The measurement of airborne $\mathrm{Hg}^{0}$, RGM and $\mathrm{PHg}$ during the Polar transect of Leg 3 (Fig. 7) indicates that the Arctic Ocean MBL during summer does not promote significant chemical conversion of $\mathrm{Hg}^{0}$ and consequently constitutes a 
minor source of RGM and PHg. The apparent variability in $\mathrm{TGM}, \mathrm{Hg}^{0}$ concentration is as previously discussed source modulated by air-sea exchange and not correlated with either RGM or PHg. The speciated-Hg observations are in concert with those of Temme et al. (2003) and Aspmo et al. (2006) for the South Atlantic and the North Atlantic/Arctic Ocean respectively during Polar summer. Observations at temperate mid-latitudes indicate that the oxidising capacity of the MBL enriched with halide-abundant aerosols may induce a significant $\mathrm{Hg}^{0}$ loss (Mason et al., 2003). However, the MBL of the Arctic Ocean during summer is distinguished by meteorological factors (high relative humidity, low visibility blocking solar radiation) not in favour of in-situ oxidation and in promotion of physical scavenging and removal of RGM and $\mathrm{PHg}$. The lack of significant diurnal variability for RGM$\mathrm{PHg}$ as well as the observed minor ratios RGM-PHg/Hg ${ }^{0}$ of a few \%o are obviously in support of a low in situ photochemical oxidation of $\mathrm{Hg}^{0}$ in the Arctic MBL. We note that the temporal features of RGM $\left(\mathrm{Hg}^{\mathrm{II}} \mathrm{X}_{2}(\mathrm{~g})\right.$ species) in convolution with relative humidity $(\mathrm{RH})$ are consistent with that of a sticky gas, which readily adsorbs onto surfaces and has a high water solubility (Fig. 7). The RGM-RH data exhibit a negative correlation with a correlation coefficient of 0.74 .

In the case of $\mathrm{CO}$, the summertime minimum can be attributed to the removal of $\mathrm{CO}$ by the reaction with hydroxyl radicals (Novelli et al., 1998); which is also more efficient during summer compared to the fall.

\section{Conclusions}

For the first time we were able to perform measurements of airborne speciated-Hg together with $\mathrm{O}_{3}$ and $\mathrm{CO}$ over major parts of the Arctic Ocean and adjacent seas during the polar summer period. The prevalent conditions of the Arctic MBL during the expedition resulted in relatively narrow statistical distributions of the trace gases (especially for $\mathrm{CO}$ ). The largest relative variability was present in the TGM, $\mathrm{Hg}^{0}$ data set during July, where generally higher concentrations were measured over the ice-capped sea. The results presented in this paper suggest the Arctic Ocean during summer to be a significant source of $\mathrm{Hg}^{0}$ to the atmosphere. ODEs and MDEs, which occur regularly during polar spring, were not observed and, therefore, do not contribute to the removal of mercury and $\mathrm{O}_{3}$ during summer. This agrees well with the seasonal cycle of $\mathrm{BrO}$ in high latitudes derived from remote sensing data (Hollwedel et al., 2004). BrO is one of the intermediate species generated during the ODEs and hence can be used as an indicator for such events. Nevertheless, $\mathrm{O}_{3}$ values lower than in the background air of the North Atlantic indicate an ongoing removal of $\mathrm{O}_{3}$ from the Arctic MBL in summer probably due to a combination of chemical and physical processes. The good agreement between the ship-borne measurements of TGM, $\mathrm{Hg}^{0} ; \mathrm{O}_{3}$ and $\mathrm{CO}$ and the observations at Alert and Barrow indicate that the observed seasonal varia- tion between July and September are representative for the entire Arctic. In terms of an abrupt future warming, the current cycling of $\mathrm{Hg}$ in the Arctic will be largely perturbed and sea-air interaction will be even more important in its atmospheric behaviour.

Acknowledgements. The Swedish Polar Secretariat is acknowledged for organising and including our project in the BERINGIA 2005 expedition. The Captain and crew of IB Oden are greatly appreciated for the support and help onboard. Special thanks go to Christian Temme (previously at G. K. S. S. Research Centre, Geesthacht, Germany) for kindly providing an analytical instrument for the expedition. The authors thank Paul Novelli (NOAA/ESRL), Alexandra Steffen (Environment Canada) and Doug Worthy (Environment Canada) for providing unpublished data from Barrow and Alert and the Japan Meteorological Agency for maintaining the WMO World Data Centre for Greenhouse Gases. The authors gratefully acknowledge Yaqiang Wang for producing and making the TrajStat software available, NOAA Air Resources Laboratory (ARL) for the provision of the HYSPLIT transport and dispersion model and READY website (www.arl.noaa.gov/ready.html) used in this publication. This research was partly supported by grants from the German Academic Exchange Service (DAAD) and the Swedish Foundation for International Cooperation in Research and Higher Education (STINT).

Edited by: K.-H. Kim

\section{References}

Andersson, M. E.: Transport of Mercury Species in the Environment - Exchange between Oceanic Waters and the Atmosphere, Ph.D. thesis, Department of Chemistry, Göteborg University, Sweden, 59 pp., 2008.

Andersson, M. E.: Speciation of aqueous mercury species in a cross section of the Arctic Ocean, in preparation, 2010.

Andersson, M. E., Gårdfeldt, K., Wängberg, I., and Strömberg, D.: Determination of Henry's law constant for elemental mercury, Chemosphere, 73, 587-592, 2008a.

Andersson, M. E., Sommar, J., Gårdfeldt, K., and Lindqvist, O.: Enhanced concentrations of dissolved gaseous mercury in the surface waters of the Arctic Ocean, Mar. Chem., 110, 190-194, 2008 b.

Andersson, M. E., Gårdfeldt, K., and Wängberg, I.: A description of an automatic continuous equilibrium system for the measurement of dissolved gaseous mercury, Anal. Bioanal. Chem. 391, 2277-2282, 2008c.

Ariya, P. A., Dastoor, A. P., Amyot, M., Schroeder, W. H., Barrie, L., Anlauf, K., Raofie, F., Ryzhkov, A., Davignon, D., Lalonde, J., and Steffen, A.: The Arctic: a sink for mercury, Tellus Ser. B-Chem. Phys. Meteorol., 56, 397-403, 2004.

Aspmo, K., Temme, C., Berg, T., Ferrari, C., Gauchard, P.-A., Fain, X., and Wibetoe, G.: Mercury in the Atmosphere, Snow and Melt Water Ponds in the North Atlantic Ocean during Arctic Summer, Environ. Sci. Technol., 40, 4083-4089, 2006.

Banic, C. M., Beauchamp, S. T., Tordon, R. J., Schroeder, W. H., Steffen, A., Anlauf, K. A., and Wong, H. K. T.: Vertical distribution of gaseous elemental mercury in Canada, J. Geophys. Res.-Atmos., 108, 4264, doi:10.1029/2002JD002116, 2003. 
Berg, T., Sekkesæter, S., Steinnes, E., Valdal, A.-K., and Wibetoe, G.: Arctic springtime depletion of mercury in the European Arctic as observed at Svalbard, Sci. Total Environ., 304, 43-51, 2003.

Brooks, S. B., Saiz-Lopez, A., Skov, H., Lindberg, S. E., Plane, J. M. C., and Goodsite, M. E.: The mass balance of mercury in the springtime arctic environment, Geophys. Res. Lett., 33, LI3812, doi:10.1029/2005GL025525, 2006.

Calvert, J. G., and Lindberg, S. E.: Mechanisms of mercury removal by $\mathrm{O}_{3}$ and $\mathrm{OH}$ in the atmosphere, Atmos. Environ., 39, 33553367, 2005.

Dastoor, A. P., Davignon, D., Theys, N., Van Roozendael, M., Steffen, A., and Ariya, P. A.: Modeling Dynamic Exchange of Gaseous Elemental Mercury at Polar Sunrise, Environ. Sci. Technol., 42, 5183-5188, 2008.

Donohoue, D. L., Bauer, D., Cossairt, B., and Hynes, A. J.: Temperature and Pressure Dependent Rate Coefficients for the Reaction of $\mathrm{Hg}$ with $\mathrm{Br}$ and the Reaction of $\mathrm{Br}$ with $\mathrm{Br}$ : A Pulsed Laser Photolysis-Pulsed Laser Induced Fluorescence Study, J. Phys. Chem. A, 110, 6623-6632, 2006.

Draxler, R. R., and Rolph, G. D.: HYSPLIT (HYbrid SingleParticle Lagrangian Integrated Trajectory) Model access via NOAA ARL READY Website (http://www.arl.noaa.gov/ready/ hysplit4.html), NOAA Air Resources Laboratory, Silver Spring, MD. 2003.

Ebinghaus, R., Kock, H. H., Temme, C., Einax, J. W., Löwe, A. G., Richter, A., Burrows, J. P., and Schroeder, W. H.: Antarctic springtime depletion of atmospheric mercury, Environ. Sci. Technol., 36, 1238-1244, 2002.

Ebinghaus, R., Slemr, F., Brenninkmeijer, C. A. M., van Velthoven, P., Zahn, A., Hermann, M., O'Sullivan, D. A., and Oram, D. E.: Emissions of gaseous mercury from biomass burning in South America in 2005 observed during CARIBIC flights, Geophys. Res. Lett., 34, L08813, doi:10.1029/2006GL028866, 2007.

Eneroth, K., Holmén, K., Berg, T., Schmidbauer, N., and Solberg, S.: Springtime depletion of tropospheric ozone, gaseous elemental mercury and non-methane hydrocarbons in the European Arctic, and its relation to atmospheric transport, Atmos. Environ., 41, 8511-8526, 2007.

Gallagher, M. W., Beswick, K. M., and Coe, H.: Ozone deposition to coastal waters, Quart. J. R. Met. Soc. 127, 539-558, 2001.

Gerbig, C., Schmitgen, S., Kley, D., Volz-Thomas, A., Dewey, K., and Haaks, D.: An improved fast-response vacuum-UV resonance fluorescence CO instrument, J. Geophys. Res.-Atmos., 104, 1699-1704, 1999.

Hedgecock, I. M., Pirrone, N., and Sprovieri, F.: Chasing quicksilver northward: mercury chemistry in the Arctic troposphere, Environ. Chem., 5, 131-134, 2008.

Helmig, D., Oltmans, S. J., Carlson, D., Lamarque, J.-F., Jones, A., Labuschagne, C., Anlauf, K., and Hayden, K.: A review of surface ozone in the polar regions, Atmos. Environ., 41, 51385161, 2007.

Helmig, D., Cohen, L. D., Bocquet, F., Oltmans, S., Grachev, A., and Neff W.: Spring and summertime diurnal surface ozone fluxes over the polar snow at Summit, Greenland, Geophys. Res. Lett., 36, L08809, doi:10.1029/2008GL036549, 2009.

Hirdman, D., Aspmo, C., Burkhart, J.F., Eckhardt, S., Sodemann, H., and Stohl, A.: 2009, Transport of mercury in the Arctic atmosphere: Evidence for a spring-time net sink and summer-time source, Geophys. Res. Lett., 36, L12814, doi:10.1029/2009GL038345, 2009.

Holland, M. M., Bitz, C. M., and Tremblay, B.: Future abrupt reductions in the summer Arctic sea ice, Geophys. Res. Lett., 33, L23503, doi:10.1029/2006GL028024, 2006.

Holloway, T., Levy II, H., and Kasibhatla, P.: Global distribution of carbon monoxide, J. Geophys. Res., 105, 12123-12147, 2000.

Hollwedel, J., Wenig, M., Beirle, S., Kraus, S., Kuhl, S., WilmsGrabe, W., Platt, U., and Wagner, T.: Year-to-year variations of spring time polar tropospheric $\mathrm{BrO}$ as seen by GOME, Trace Constituents in the Troposphere and Lower Stratosphere, 34, 804-808, doi:10.1016/j.asr.2003.08.060, 2004.

Hönninger, G.: Halogen Oxide Studies in the Boundary Layer by Multi Axis Differential Optical Absorption Spectroscopy and Active Longpath-DOAS., Ph D. Thesis, Institute of Environmental Physics, University of Heidelberg, Germany, 262 pp., 2002.

IHO, 1953: Limits of Oceans and Seas, Special Publication 23, International Hydrographic Organization, Monaco.

Jacobi, H. W. and Schrems, O.: Peroxyacetyl nitrate (PAN) distribution over the South Atlantic Ocean, Phys. Chem. Chem. Phys., 1, 5517-5521, 1999.

Jacobi, H. W., Kaleschke, L., Richter, A., Rozanov, A., and Burrows, J. P.: Observation of a fast ozone loss in the marginal ice zone of the Arctic Ocean, J. Geophys. Res.-Atmos., 111, D15309, doi:10.1029/2005JD006715, 2006.

Jaffe, D., Prestbo, E., Swartzendruber, P., Weiss-Penzias, P., Kato, S., Takami, A., Hatakeyama, S., and Kajii, Y.: Export of atmospheric mercury from Asia, Atmos. Environ., 39, 3029-3038, 2005.

Kaleschke, L., Richter, A., Burrows, J., Afe, O., Heygster, G., Notholt, J., Rankin, A. M., Roscoe, H. K., Hollwedel, J., Wagner, T., and Jacobi, H. W.: Frost flowers on sea ice as a source of sea salt and their influence on tropospheric halogen chemistry, Geophys. Res. Lett., 31, L16114, doi:10.1029/2004GL020655, 2004.

Kellerhals, M., Beauchamp, S., Belzer, W., Blanchard, P., Froude, F., Harvey, B., McDonald, K., Pilote, M., Poissant, L., Puckett, K., Schroeder, B., Steffen, A., and Tordon, R.: Temporal and spatial variability of total gaseous mercury in Canada: results from the Canadian Atmospheric Mercury Measurement Network (CAMNet), Atmos. Environ., 37, 1003-1011, 2003.

Kim, K. H., Ebinghaus, R., Schroeder, W. H., Blanchard, P., Kock, H. H., Steffen, A., Froude, F. A., Kim, M. Y., Hong, S. M., and Kim, J. H.: Atmospheric mercury concentrations from several observatory sites in the northern hemisphere, J. Atmos. Chem., 50, 1-24, 2005.

Kock, H. H., Bieber, E., Ebinghaus, R., Spain, T. G., and Thees, B.: Comparison of long-term trends and seasonal variations of atmospheric mercury concentrations at the two European coastal monitoring stations Mace Head, Ireland, and Zingst, Germany, Atmos. Environ., 39, 7549-7556, 2005.

Lahoutifard, N., Poissant, L., and Scott, S. L.: Scavenging of gaseous mercury by acidic snow at Kuujjuarapik, Northern Quebec, Sci. Total Environ., 355, 118-126, 2006.

Laurier, F. J. G., Mason, R. P., Whalin, L., and Kato, S.: Reactive gaseous mercury formation in the North Pacific Ocean's marine boundary layer: A potential role of halogen chemistry, J. Geophys. Res.-Atmos., 108, L16114, doi:10.1029/2003JD003625, 2003. 
Lemke, P., J. Ren, R.B. Alley, I. Allison, J. Carrasco, G. Flato, Y. Fujii, G. Kaser, P. Mote, R.H. Thomas and T. Zhang, 2007: Observations: Changes in Snow, Ice and Frozen Ground. In: Climate Change 2007: The Physical Science Basis. Contribution of Working Group I to the Fourth Assessment Report of the Intergovernmental Panel on Climate Change, edited by: Solomon, S., Qin, D., Manning, M., Chen, Z., Marquis, M., Averyt, K. B., Tignor, M., and Miller, H. L., Cambridge University Press, Cambridge, United Kingdom and New York, NY, USA.

Lockhart, W. L., Stern, G. A., Wagemann, R., Hunt, R. V., Metner, D. A., DeLaronde, J., Dunn, B., Stewart, R. E. A., Hyatt, C. K., Harwood, L., and Mount, K.: Concentrations of mercury in tissues of beluga whales (Delphinapterus leucas) from several communities in the Canadian Arctic from 1981 to 2002, Sci. Total Environ., 351, 391-412, 2005.

Mason, R. P., Laurier, F. J. G., Whalin, L., and Sheu, G. R.: The role of ocean-atmosphere exchange in the global mercury cycle, J. Phys. IV, 107, 835-838, 2003.

Nightingale, P. D., Malin, G., Law, C. S., Watson, A. J., Liss, P. S., Liddicoat, M. I., Boutin, J., and Upstill-Goddard, R. C.: In situ evaluation of air-sea gas exchange parameterizations using novel conservative and volatile tracers, Glob. Biogeochem. Cycle, 14, 373-387, 2000.

Novelli, P. C., Masarie, K. A., and Lang, P. M.: Distributions and recent changes of carbon monoxide in the lower troposphere, J. Geophys. Res.-Atmos., 103, 19015-19033, 1998.

Obrist, D.: Atmospheric mercury pollution due to losses of terrestrial carbon pools?, Biogeochemistry, 85, 119-123, 2007.

Outridge, P. M., Macdonald, R. W., Wang, F., Stern, G. A., and Dastoor, A. P.: A mass balance inventory of mercury in the Arctic Ocean, Environ. Chem., 5, 89-111, 2008.

Poulain, A. J., Chadhain, S. M. N., Ariya, P. A., Amyot, M., Garcia, E., Campbell, P. G. C., Zylstra, G. J., and Barkay, T.: Potential for mercury reduction by microbes in the high Arctic, Appl. Environ. Microb., 73, 2230-2238, 2007a.

Poulain, A. J., Garcia, E., Amyot, M., Campbell, P. G. C., and Ariya, P. A.: Mercury distribution, partitioning and speciation in coastal vs. inland High Arctic snow, Geochim. Cosmochim. Acta, 71, 3419-3431, 2007b.

Schroeder, W. H., Anlauf, K. G., Barrie, L. A., Lu, J. Y., Steffen, A., Schneeberger, D. R., and Berg, T.: Arctic springtime depletion of mercury, Nature, 394, 331-332, 1998.

Schroeder, W. H., Steffen, A., Scott, K., Bender, T., Prestbo, E., Ebinghaus, R., Lu, J. Y., and Lindberg, S. E.: Summary report: first international Arctic atmospheric mercury research workshop, Atmos. Environ., 37, 2551-2555, 2003.

Sigler, J. M., Lee, X., and Munger, W.: Emission and long-range transport of gaseous mercury from a large-scale Canadian boreal forest fire, Environ. Sci. Technol., 37, 4343-4347, 2003.

Simpson, W., Alvarez-Avilies, L., Douglas, T. A., Sturm, M., and Domine, F.: Halogens in the coastal snow pack near Barrow, Alaska: Evidence for active bromine air-snow chemistry during springtime, Geophys. Res. Lett., 32, L04811, doi:10.1029/2004GL021748, 2005.

Simpson, W. R., von Glasow, R., Riedel, K., Anderson, P., Ariya, P., Bottenheim, J., Burrows, J., Carpenter, L. J., Frie, U., Goodsite, M. E., Heard, D., Hutterli, M., Jacobi, H.-W., Kaleschke, L., Neff, B., Plane, J., Platt, U., Richter, A., Roscoe, H., Sander, R., Shepson, P., Sodeau, J., Steffen, A., Wagner, T., and Wolff,
E.: Halogens and their role in polar boundary-layer ozone depletion, Atmos. Chem. Phys., 7, 4375-4418, doi:10.5194/acp-74375-2007, 2007.

Skov, H., Christensen, J. H., Goodsite, M. E., Heidam, N. Z., Jensen, B., Wåhlin, P., and Geernaert, G.: Fate of Elemental Mercury in the Arctic during Atmospheric Mercury Depletion Episodes and the Load of Atmospheric Mercury to the Arctic, Environ. Sci. Technol., 54, 2373-2382, 2004.

Slemr, F., Schuster, G., and Seiler, W.: Distribution, speciation, and budget of atmospheric mercury, J. Atmos. Chem., 3, 407-434, 1985.

Slemr, F., Ebinghaus, R., Simmonds, P. G., and Jennings, S. G.: European emissions of mercury derived from long-term observations at Mace Head, on the western Irish coast, Atmos. Environ., 40, 6966-6974, 2006.

Slemr, F., Brunke, E. G., Labuschagne, C., and Ebinghaus, R.: Total gaseous mercury concentrations at the Cape Point GAW station and their seasonality, Geophys. Res. Lett., 35, L11807, doi:10.1029/2008GL033741, 2008.

Sommar, J., Hallquist, M., Ljungström, E., and Lindqvist, O.: On the gas phase reactions between volatile biogenic mercury species and the nitrate radical, J. Atmos. Chem., 27, 233-247, 1997.

Sommar, J., Gårdfeldt, K., Strömberg, D., and Feng, X. B.: A kinetic study of the gas-phase reaction between the hydroxyl radical and atomic mercury, Atmos. Environ., 35, 3049-3054, 2001.

Sommar, J., Wängberg, I., Berg, T., Gårdfeldt, K., Munthe, J., Richter, A., Urba, A., Wittrock, F., and Schroeder, W. H.: Circumpolar transport and air-surface exchange of atmospheric mercury at Ny-Ålesund $\left(79^{\circ} \mathrm{N}\right)$, Svalbard, spring 2002, Atmos. Chem. Phys., 7, 151-166, doi:10.5194/acp-7-151-2007, 2007.

St Louis, V. L., Hintelmann, H., Graydon, J. A., Kirk, J. L., Barker, J., Dimock, B., Sharp, M. J., and Lehnherr, I.: Methylated mercury species in Canadian high Arctic marine surface waters and snowpacks, Environ. Sci. Technol., 41, 6433-6441, 2007.

Steffen, A., Schroeder, W. H., Macdonald, R. W., Poissant, L., and Konoplev, A.: Mercury in the Arctic atmosphere: An analysis of eight years of measurements of GEM at Alert (Canada) and a comparison with observations at Amderma (Russia) and Kuujjuarapik (Canada), Sci. Total Environ., 342, 185-198, 2005.

Steffen, A., Douglas, T., Amyot, M., Ariya, P., Aspmo, K., Berg, T., Bottenheim, J., Brooks, S., Cobbett, F., Dastoor, A., Dommergue, A., Ebinghaus, R., Ferrari, C., Gardfeldt, K., Goodsite, M. E., Lean, D., Poulain, A. J., Scherz, C., Skov, H., Sommar, J., and Temme, C.: A synthesis of atmospheric mercury depletion event chemistry in the atmosphere and snow, Atmos. Chem. Phys., 8, 1445-1482, doi:10.5194/acp-8-1445-2008, 2008.

Stohl, A.: Characteristics of atmospheric transport into the Arctic troposphere, J. Geophys. Res., 111, D11306, doi:10.1029/2005JD006888, 2006.

Stohl, A., Berg, T., Burkhart, J. F., Fjae'raa, A. M., Forster, C., Herber, A., Hov, Ø., Lunder, C., McMillan, W. W., Oltmans, S., Shiobara, M., Simpson, D., Solberg, S., Stebel, K., Strm, J., Trseth, K., Treffeisen, R., Virkkunen, K., and Yttri, K. E.: Arctic smoke - record high air pollution levels in the European Arctic due to agricultural fires in Eastern Europe in spring 2006, Atmos. Chem. Phys., 7, 511-534, doi:10.5194/acp-7-511-2007, 2007.

Sumner, A. L., Shepson, P. B., Grannas, A. M., Bottenheim, J. W., Anlauf, K. G., Worthy, D., Schroeder, W. H., Steffen, A., 
Domine, F., Perrier, S., and Houdier, S.: Atmospheric chemistry of formaldehyde in the Arctic troposphere at Polar Sunrise, and the influence of the snowpack, Atmos. Environ., 36, 2553-2562, 2002.

Wang, Y. Q., Zhang, X. Y., and Draxler, R.: TrajStat: GIS-based software that uses various trajectory statistical analysis methods to identify potential sources from long-term air pollution measurement data, Environ. Model. Software, 24, 938-939, 2009.

Wängberg, I., Munthe, J., Amouroux, D., Andersson, M. E., Fajon, V., Ferrara, R., Gårdfeldt, K., Horvat, M., Mamane, Y., Melamed, E., Monperrus, M., Ogrinc, N., Yossef, O., Pirrone, N., Sommar, J., and Sprovieri, F.: Atmospheric mercury at Mediterranean coastal stations, Environ. Fluid Mech., 8, 101116, 2008.
Wängberg, I., Munthe, J., Ebinghaus, R., Gårdfeldt, K., Iverfeldt, $\AA$., and Sommar, J.: Distribution of TPM in Northern Europe, Sci. Total Environ., 304, 53-59, 2003.

Weiss-Penzias, P., Jaffe, D. A., Swartzendruber, P., Hafner, W., Chand, D., and Prestbo, E.: Quantifying atmospheric mercury emissions from biomass burning and East Asian industrial regions based on ratios with carbon monoxide in pollution plumes at the Mount Bachelor Observatory, Atmos. Environ., 41, 43664379.

Wilhelm, S. M.: Estimate of mercury emissions to the atmosphere from petroleum, Environ. Sci. Technol., 35, 4704-4710, 2001.

Wilhelm, S. M. and Spitz, P.: Impact of mercury on crude oil quality, World Refining 13, 32-36, 2003. 